\title{
Intracellular pH Modulates the Generation of Superoxide Radicals by Human Neutrophils
}

\author{
Louis Simchowitz \\ Department of Medicine, John Cochran Veterans Administration Medical Center, and Department of Medicine, \\ Washington University School of Medicine, St. Louis, Missouri 63125
}

\section{Abstract}

The relationship of intracellular $\mathrm{pH}\left(\mathrm{pH}_{\mathrm{i}}\right)$ to superoxide radical $\left(\mathrm{O}_{2}^{-}\right)$generation was investigated in chemotactic factor-stimulated human neutrophils. Exposure of cells to $100 \mathrm{nM} N$-formylmethionyl-leucyl-phenylalanine (FMLP) caused activation of $\mathrm{Na} / \mathrm{H}$ exchange which, in $140 \mathrm{mM} \mathrm{Na}$ medium $\left(\mathrm{pH}_{0} 7.40\right)$, led to a rise in $\mathrm{pH}_{\mathrm{i}}$ from 7.22 to 7.80. This $\mathrm{pH}_{\mathrm{i}}$ change was sensitive to amiloride (apparent $K_{i} 78 \mu \mathrm{M}$ ), an inhibitor of $\mathrm{Na} / \mathrm{H}$ countertransport. The time course of the alkalinization was similar to that of FMLP-stimulated $\mathrm{O}_{2}^{-}$production, which was complete by $5 \mathrm{~min}$. In the presence of $1 \mathrm{mM}$ amiloride, which nearly blocked the $\mathrm{pH}_{\mathrm{i}}$ transient elicited by FMLP, or in the absence of external $\mathrm{Na}$, where intracellular acidification was observed in FMLP-stimulated cells, $\mathrm{O}_{2}^{-}$release was still roughly $25-45 \%$ of normal. Thus, an alkalinization cannot be an obligatory requirement for $\mathrm{O}_{2}^{-}$generation. By independently varying either $\mathrm{pH}_{0}$, $\mathrm{pH}_{i}$, or the internal or external concentrations of $\mathrm{Na}$, both the direction and magnitude of the FMLP-induced $\mathrm{pH}_{\mathrm{i}}$ transients could be altered. In each instance, the amount of $\mathrm{O}_{2}^{-}$release correlated directly with $\mathrm{pH}_{\mathrm{i}}$ and was enhanced by intracellular alkalinization.

In the absence of FMLP, a rise in $\mathrm{pH}_{\mathrm{i}}$ to 7.7-7.8 by exposure of cells to $30 \mathrm{mM} \mathrm{NH} 4 \mathrm{Cl}, 10 \mu \mathrm{M}$ monensin (a $\mathrm{Na} / \mathrm{H}$ exchanging ionophore), or after a prepulse with $18 \% \mathrm{CO}_{2}$ did not result in $\mathrm{O}_{2}^{-}$generation. Thus, these results imply that an alkalinization per se is not a sufficient trigger. Neutrophils exposed to $4 \mathrm{nM}$ FMLP exhibited a threefold slower rate of alkalinization (reaching $\mathrm{pH}_{\mathrm{i}} \sim 7.80$ by $20-30 \mathrm{~min}$ ) as compared to that obtained with $100 \mathrm{nM}$ FMLP and did not release significant amounts of $\mathrm{O}_{2}^{-}$under normal incubation conditions. However, these cells could be induced to generate $\mathrm{O}_{2}^{-}$when the degree of alkalinization was enhanced by internal $\mathrm{Na}$ depletion or by pretreatment with $18 \% \mathrm{CO}_{2}$. Together, these results indicate a modulating effect of $\mathrm{pH}_{\mathrm{i}}$ on $\mathrm{O}_{2}^{-}$production and suggest that other functional responses of neutrophils may be regulated by their $\mathrm{pH}_{\mathrm{i}}$.

\section{Introduction}

In recent years, the effects of the ionic environment on neutrophil function have received much attention. To varying degrees, random motility, chemotaxis, aggregation, phagocytosis, $\mathrm{O}_{2}^{-}$generation, and granule enzyme release have all been shown to be dependent on the extracellular concentrations of $\mathrm{K}, \mathrm{Na}$, and/or $\mathrm{Ca}(1-3)$. Although an inhibitory effect of high external $\mathrm{K}$ has

Address reprint requests to Dr. Simchowitz (151/JC), John Cochran VA Medical Center, 915 North Grand Avenue, St. Louis, MO 63125.

Received for publication 28 January 1985 and in revised form 17 May 1985.

The Journal of Clinical Investigation, Inc.

Volume 76, September 1985, 1079-1089 often been attributed to a depolarization of the membrane potential $(4,5)$, the nature of the ionic requirements for $\mathrm{Na}$ and $\mathrm{Ca}$ remain largely unexplained. Our group and others $(6,7)$ have noted a marked reduction in the amount of $\mathrm{O}_{2}^{-}$generation induced by $N$-formyl-methionyl-leucyl-phenylalanine (FMLP) ${ }^{1}$ in human neutrophils as the extracellular concentration of $\mathrm{Na}$, $[\mathrm{Na}]_{0}$, was reduced from $140 \mathrm{mM}$ to 0 by replacement with choline. It has also been observed that exposure of cells to FMLP leads to a striking depolarization of the transmembrane potential as measured by fluorescent cyanine dyes or by radiolabeled triphenylmethylphosphonium ion $(5,8-10)$. In view of this, alterations in responses consequent to variations in $[\mathrm{Na}]_{0}$ have been ascribed to changes in the $\mathrm{Na}$ current $(6,7,11)$, analogous to the role of external $\mathrm{Na}$ in propagating the action potential in excitable tissues such as muscle and nerve (12).

Recently, Naccache, Sha'af, and co-workers reported that FMLP stimulates unidirectional in- and effluxes of ${ }^{22} \mathrm{Na}$ in rabbit peritoneal neutrophils $(11,13)$. The enhanced ${ }^{22} \mathrm{Na}$ fluxes occurred in association with a $\mathrm{pH}_{\mathrm{i}}$ transient (i.e., prolonged alkalinization [14]), both of which were blocked by amiloride (15, 16), an inhibitor of $\mathrm{Na} / \mathrm{H}$ exchange (17). These findings have been confirmed and extended in human neutrophils by our group $(6,18,19)$. In these studies $(18,19)$, we observed that, after exposure of human neutrophils to $100 \mathrm{nM}$ FMLP in $140 \mathrm{mM}$ $\mathrm{Na}$ medium, $\mathrm{pH}_{0} 7.40$, there was an increase in the steady-state intracellular $\mathrm{Na}$ concentration, $[\mathrm{Na}]_{i}$, from $\sim 30$ to $60 \mathrm{meq} / \mathrm{liter}$ cell water and an increase in steady-state $\mathrm{pH}_{\mathrm{i}}$ from a resting value of $\sim 7.25$ to 7.80 . These steady-state values in FMLPactivated neutrophils are those predicted for an equilibrium distribution of $\mathrm{Na}$ and $\mathrm{H}$ across the cell membrane as mediated by a $\mathrm{Na} / \mathrm{H}$ exchanger of $1: 1$ stoichiometry. The distribution, at chemical equilibrium, is governed by the equation:

$\frac{[\mathrm{Na}]_{0}}{[\mathrm{Na}]_{\mathrm{i}}}=\frac{[\mathrm{H}]_{0}}{[\mathrm{H}]_{\mathrm{i}}}$.

It thus appears that the chemotactic factor activates an amiloridesensitive $\mathrm{Na} / \mathrm{H}$ countertransport which mediates an alkalinization of $\mathrm{pH}_{\mathrm{i}}$ via the net uptake of external $\mathrm{Na}$ in exchange for internal $\mathrm{H}$.

The nature of the dependence of several different functional responses on $[\mathrm{Na}]_{0}$ may therefore be due to the ion's serving as a substrate in the $\mathrm{Na} / \mathrm{H}$ exchange reaction. This led us to investigate whether $\mathrm{a} \mathrm{pH}_{\mathrm{i}}$ transient, specifically an alkalinization, might be a requirement for or regulate $\mathrm{O}_{2}^{-}$production. Considering the interrelationships between $\mathrm{Na}$ and $\mathrm{H}$ as dictated by Eq. 1, we were able to vary each of the four parameters independently in order to alter both the direction and magnitude of

1. Abbreviations used in this paper: DMO, 5,5-dimethyloxazolidine-2,4dione; DMSO, dimethylsulfoxide; FMLP, $N$-formyl-methionyl-leucylphenylalanine; MES, 2-( $N$-morpholino)-ethanesulfonic acid; Tricine, $N$ tris(hydroxymethyl)methylglycine. 
the $\mathrm{pH}_{\mathrm{i}}$ changes induced by FMLP. By measuring the release of $\mathrm{O}_{2}^{-}$under these conditions, we were able to correlate $\mathrm{pH}_{\mathrm{i}}$ responses with the degree of $\mathrm{O}_{2}^{-}$generation and therefore, to determine the relationship of $\mathrm{pH}_{\mathrm{i}}$ to $\mathrm{O}_{2}^{-}$production. We find that, in cells activated by FMLP, an alkalinization of $\mathrm{pH}_{\mathrm{i}}$ is not an obligatory requirement for $\mathrm{O}_{2}^{-}$generation because substantial $\mathrm{O}_{2}^{-}$release $(25-45 \%$ of total) occurs in the presence of $1 \mathrm{mM}$ amiloride (which nearly blocks the alkalinization, $\mathrm{pH}_{\mathrm{i}}$ remaining unchanged at $\sim 7.25$ ) or in the nominal absence of extracellular $\mathrm{Na}$ (where $\mathrm{pH}_{\mathrm{i}}$ acidifies to $\sim 6.8$ ). In addition, in the absence of FMLP, an alkalinization of $\mathrm{pH}_{\mathrm{i}}$ to levels (7.7-7.8) obtained under normal conditions with an optimal dose (100 nM) of FMLP did not result in detectable $\mathrm{O}_{2}^{-}$generation. Thus, an alkalinization of $\mathrm{pH}_{\mathrm{i}}$ of this degree is not, by itself, a sufficient trigger. However, in cells exposed to $100 \mathrm{nM}$ FMLP, we find that the $\mathrm{pH}_{\mathrm{i}}$ appears to modulate the amount of $\mathrm{O}_{2}^{-}$production, an alkalinization tending to enhance or potentiate the release of this product of the respiratory burst.

\section{Methods}

\section{Incubation media}

The standard medium used throughout this study had the following composition: $140 \mathrm{mM} \mathrm{NaCl}, 5 \mathrm{mM} \mathrm{KCl}, 1 \mathrm{mM} \mathrm{CaCl}_{2}, 0.5 \mathrm{mM} \mathrm{MgCl}$, $5.6 \mathrm{mM}$ glucose, $5 \mathrm{mM}$ Hepes buffer, $\mathrm{pH} 7.40$, and $1 \mathrm{mg} / \mathrm{ml}$ of crystalline bovine serum albumin. To test the effects of varying external $\mathrm{Na}$, media of appropriate [Na] $]_{0}$ were prepared by equimolar substitution of $N$ methyl-D-glucamine for $\mathrm{Na}$. $\mathrm{N}$-methyl-D-glucamine, rather than choline, was chosen as the replacement for $\mathrm{Na}$ for the following reason. In preliminary studies, we found that even a short $(\sim 5 \mathrm{~min})$ exposure to high choline concentrations $\left(\geq 50 \mathrm{mM}\right.$ ) caused marked inhibition of $\mathrm{O}_{2}^{-}$release when cells were subsequently resuspended in $140 \mathrm{mM} \mathrm{Na}$ medium and stimulated with FMLP. In contrast, cells pretreated in Na-free, $140 \mathrm{mM}$ $\mathrm{N}$-methyl-D-glucamine-containing medium for $5 \mathrm{~min}$ displayed a normal $\mathrm{O}_{2}^{-}$generation response when the cells were then exposed to FMLP in $140 \mathrm{mM} \mathrm{Na}$. This suggests that at least part of the inhibitory effect of choline medium noted above is due, not to the reduction in external $\mathrm{Na}$, but rather to the presence of choline or, perhaps, to a contaminant.

In some instances, the experimental media were buffered with $5 \mathrm{mM} 2-(N$-morpholino)ethanesulfonic acid (MES) (pKa 6.0) or $N$ tris(hydroxymethyl)methylglycine (Tricine) $\left(\mathrm{pK}_{\mathrm{a}}^{\prime} 7.8\right)$ instead of Hepes ( $\mathrm{pK}_{\mathrm{a}}^{\prime}$ 7.3), depending upon the extracellular $\mathrm{pH}\left(\mathrm{pH}_{0}\right)$ of the media (5.98.0). Solutions containing $30 \mathrm{mM} \mathrm{NH}_{4} \mathrm{Cl}$ were obtained by equimolar substitution of $\mathrm{NH}_{4} \mathrm{Cl}$ for $\mathrm{NaCl}$.

$\mathrm{CO}_{2}$-containing solutions were prepared as follows: a stock solution containing $5 \mathrm{mM}$ Hepes and normal amounts of other ions was gassed with a $20 \% \mathrm{CO}_{2} / 80 \% \mathrm{O}_{2}$ mixture. Sufficient $\mathrm{NaHCO}_{3}(109 \mathrm{mM}$, replacing $\mathrm{NaCl}$ ) was added to bring the $\mathrm{pH}_{0}$ to 7.40 . This stock was anaerobically diluted with different volumes of standard medium $\left(\mathrm{pH}_{0} 7.40\right)$ also containing $5 \mathrm{mM}$ Hepes, in order to obtain solutions of different $\mathrm{CO}_{2}$ concentrations ( 5 and $18 \%$ ), but identical $\mathrm{pH}_{0}$. The tubes containing these solutions, which were overlaid with mineral oil, were capped during the cell incubation.

\section{Cell isolation}

Neutrophils were isolated from heparinized blood of normal donors by the standard procedure of dextran sedimentation at $37^{\circ} \mathrm{C}$ followed by Ficoll-Hypaque gradient centrifugation at room temperature (20). The cellular pellet was resuspended for $30 \mathrm{~s}$ in distilled water to lyse any red cells present. Isotonicity was then restored by addition of $\mathrm{NaCl}$ solution, after which the cells were washed twice in standard medium $\left(\mathrm{pH}_{0} 7.40\right)$. The cells were kept in this medium for $1 \mathrm{~h}$ at $37^{\circ} \mathrm{C}$ before experimentation. About $97 \%$ of the cell suspension consisted of neutrophils. Vital dyes, either eosin $Y$ or trypan blue, when added to the suspension, were excluded by $>99 \%$ of the cells, a generally accepted criterion of viability.

As previously reported (21), the resting cytoplasmic $\mathrm{pH}_{\mathrm{i}}$ of steady- state human neutrophils bathed in nominally $\mathrm{CO}_{2}$-free standard medium $\left(\mathrm{pH}_{0} 7.40\right)$ is $\sim 7.25$. Cells of more acidic $\mathrm{pH}_{\mathrm{i}}$ were obtained by means of the undershoot of $\mathrm{pH}_{\mathrm{i}}$ after an $\mathrm{NH}_{4} \mathrm{Cl}$ prepulse as described below (21, but see reference 22 for review). Neutrophils were exposed to 30 $\mathrm{mM} \mathrm{NH}{ }_{4} \mathrm{Cl}$ at $\mathrm{pH}_{0} 7.40$ for $30 \mathrm{~min}$ at $37^{\circ} \mathrm{C}$. Under these conditions, $\mathrm{pH}_{\mathrm{i}}$ rises immediately to $\sim 7.65$ and then declines exponentially, approaching control values by $30 \mathrm{~min}$. When, after 30 minutes, the $\mathrm{NH}_{4} \mathrm{Cl}$ is removed and the cells resuspended in $\mathrm{NH}_{4} \mathrm{Cl}$-free standard medium (constant $\mathrm{pH}_{0}$ ), $\mathrm{pH}_{\mathrm{i}}$ strikingly falls to $\sim 6.5$, a value $\sim 0.75$ below control. After the undershoot, $\mathrm{pH}_{\mathrm{i}}$ promptly recovers to near resting values by 15 min. The rapid initial $\mathrm{pH}_{\mathrm{i}}$ rise upon exposure to $\mathrm{NH}_{4} \mathrm{Cl}$, which has been described in a variety of cell types (22), is due to the entry and subsequent protonation of $\mathrm{NH}_{3}$. The ensuing recovery during maintained $\mathrm{NH}_{4} \mathrm{Cl}$ exposure can be interpreted as due to the entry of $\mathrm{H}^{+}$equivalents. The resulting intracellular accumulation of $\mathrm{H}^{+}$equivalents leads to a $\mathrm{pH}_{\mathrm{i}}$ undershoot when $\mathrm{NH}_{4} \mathrm{Cl}$ is removed, because most of the intracellular $\mathrm{NH}_{4}^{+}$leaves as $\mathrm{NH}_{3}(22)$.

Neutrophils of more alkaline $\mathrm{pH}_{\mathrm{i}}$ were prepared by means of the overshoot of $\mathrm{pH}_{\mathrm{i}}$ after a $\mathrm{CO}_{2}$ prepulse as described below $(21,22)$. Cells were exposed to $5 \%$ or $18 \% \mathrm{CO}_{2}$ for $30 \mathrm{~min}$ at $37^{\circ} \mathrm{C}$. Upon application of $18 \% \mathrm{CO}_{2}$ at constant $\mathrm{pH}_{0}(7.40), \mathrm{pH}_{\mathrm{i}}$ falls immediately to $\sim 6.80$. Over the next 20-30 min, $\mathrm{pH}_{\mathrm{i}}$ recovers by $0.2 \mathrm{U}$ to $\sim 7.00$, after which it remains unchanged. When, after $30 \mathrm{~min}$ of $\mathrm{CO}_{2}$ exposure, the cells are resuspended in $\mathrm{CO}_{2}$-free standard medium $\left(\mathrm{pH}_{0} 7.40\right)$, the $\mathrm{pH}_{\mathrm{i}}$ rapidly rises to $\sim 7.75$, that is, $\sim 0.5 \mathrm{U}$ above control. $\mathrm{The}_{\mathrm{pH}}$ then returns towards the original value over the course of the following $15 \mathrm{~min}$. The $\mathrm{pH}_{\mathrm{i}}$ fall upon $\mathrm{CO}_{2}$ application is due to the entrance and subsequent hydration and dissociation of molecular $\mathrm{CO}_{2}$. The subsequent alkalinization during maintained $\mathrm{CO}_{2}$ exposure can be interpreted as the result of removal of $\mathrm{H}^{+}$equivalents from the cells. The resulting intracellular $\mathrm{H}^{+}$deficit leads to a $\mathrm{pH}_{\mathrm{i}}$ overshoot upon $\mathrm{CO}_{2}$ removal. For this study, cells were exposed to 5 or $18 \% \mathrm{CO}_{2}$. In the former instance, the $\mathrm{pH}_{\mathrm{i}}$ changes were qualitatively similar to the above though of lesser magnitude.

\section{Reagents}

The following chemicals were purchased from Sigma Chemical Company, St. Louis, MO: 5,5-dimethyloxazolidine-2,4-dione (DMO), $N$-methylD-glucamine, HEPES, MES, Tricine, mineral oil, ferricytochrome $c$ (type III), superoxide dismutase, crystalline bovine serum albumin, FMLP, and cytochalasin B. FMLP and cytochalasin B were dissolved at $1 \mathrm{mM}$ and $5 \mathrm{mg} / \mathrm{ml}$, respectively, in dimethylsulfoxide (DMSO, Fisher Scientific Co., St. Louis, MO) and then diluted in medium. The resultant final concentrations of DMSO $(\leq 0.1 \%)$ had no detectable effect on any of the assays. Isotopes: $\left[{ }^{3} \mathrm{H}\right] \mathrm{H}_{2} \mathrm{O},\left[{ }^{14} \mathrm{C}\right] \mathrm{DMO}$, and $\left[{ }^{14} \mathrm{C}\right]$ inulin were purchased from New England Nuclear, Boston, MA. Amiloride was a gift of Dr. Edward J. Cragoe, Jr., of the Merck, Sharp, \& Dohme Research Institute, West Point, PA. Cells were pretreated with amiloride for 2 min before experimentation; longer preincubations with the drug were without further effect.

\section{pH $H_{i}$ measurements with $\mathrm{DMO}$}

All experiments were conducted at $37^{\circ} \mathrm{C}$. We derived $\mathrm{pH}_{\mathrm{i}}$ from the steadystate distribution of the $\left[{ }^{14} \mathrm{C}\right]$-labeled weak acid, DMO, pK 6.13 (23). The DMO method has been recently reviewed (22). The charged form of this compound is assumed to be impermeant, so that, at steady state, the uncharged partner is equilibrated across the plasma membrane. At known $\mathrm{pH}_{0}, \mathrm{pH}_{\mathrm{i}}$ can then be derived from the equilibrium distribution of the indicator. At the shortest practical exposure time, $15 \mathrm{~s}$, equilibrium of DMO has already been achieved, as evidenced by unchanged distribution for the next $60 \mathrm{~min}(21)$. Thus, the probe is suitable for kinetic analyses during which $\mathrm{pH}_{\mathrm{i}}$ is changing rapidly.

Samples of the neutrophil suspension $\left(8-12 \times 10^{6} \mathrm{cells} / \mathrm{ml}\right)$, containing $\left[{ }^{14} \mathrm{C}\right] \mathrm{DMO}(1.0 \mu \mathrm{Ci} / \mathrm{ml})$ were incubated in plastic tubes at $37^{\circ} \mathrm{C}$ under various experimental conditions. Unlabeled indicator was added to a total concentration of $0.1 \mathrm{mM}$ which does not affect $\mathrm{pH}_{\mathrm{i}}$ as assessed by the fluorescence of 6-carboxyfluorescein, another $\mathrm{pH}_{\mathrm{i}}$ probe (21). At intervals, triplicate aliquots of the cell suspensions were layered over 0.7 $\mathrm{ml}$ of Versilube F50 oil (Harwick Chemical Corp., Akron, OH) in 1.5- 
$\mathrm{ml}$ plastic tubes, which were then centrifuged for $\sim 30 \mathrm{~s}$ at $8,000 \mathrm{~g}$ in a microcentrifuge (Beckman Instruments, Inc., Palo Alto, CA). The cells penetrate the oil and accumulate as a pellet, while the suspending medium remains above the oil. This layering method, introduced by Naccache et al. (13), allows cell separation in $<5 \mathrm{~s}$. The pellets were isolated and counted in a liquid scintillation counter (Beckman Instruments, Inc., LS 7000) after addition of $10 \mathrm{ml}$ Aquasol-2 (New England Nuclear). In preliminary studies, $\left[{ }^{14} \mathrm{C}\right]$ inulin was added as a marker for the extracellular space. The indicator content of the cells could thus be corrected for the medium trapped in the pellet. The extracellular water was $9 \pm 2 \%$ ( $n$ $=7$ ) of total pellet water (21). In these inulin studies as well as in all others, total water was measured with $\left[{ }^{3} \mathrm{H}\right] \mathrm{H}_{2} \mathrm{O}$.

We have found that, upon addition of FMLP to a suspension of human neutrophils, only $\sim 60 \%$ of the total number of cells actually exhibit a stimulation of ${ }^{22} \mathrm{Na}$ fluxes (19). With respect to ${ }^{22} \mathrm{Na}$ fluxes, the remainder of the cells $(\sim 40 \%)$ behave as nonresponders. Because the enhanced ${ }^{22} \mathrm{Na}$ in- and effluxes observed after exposure to FMLP may be solely ascribed to transport via $\mathrm{Na} / \mathrm{H}$ exchange, it follows that only $60 \%$ of cells will respond with a $\mathrm{pH}_{\mathrm{i}}$ change. This conclusion, that ${ }^{22} \mathrm{Na}$ fluxes and $\mathrm{pH}_{\mathrm{i}}$ transients mirror the same transport process, is based on the quantitative $(1: 1)$ relationship between the two, as well as on their parallel and complete sensitivity to amiloride $(18,19)$. In our laboratory, the fraction of FMLP-responders $(58.7 \pm 2.6 \%, n=6)$ is similar to the value of $65.0 \pm 5.0 \%(n=7)$ reported by Seligmann et al. (24), who observed functional heterogeneity to FMLP in human neutrophils by means of flow cytometry using a voltage-sensitive cyanine dye. Taking into account the existence of discrete neutrophil subpopulations, the DMOderived $\mathrm{pH}_{\mathrm{i}}$ in the bulk cell suspension, $\overline{\mathrm{pH}}_{\mathrm{DMO}}$, was used to calculate the cytoplasmic $\mathrm{pH}_{\mathrm{i}}$ in the FMLP-responding subpopulation, $\mathrm{pH}_{\mathrm{i}}{ }^{\mathrm{FMP}}$, according to the expression (22):

$\overline{\mathrm{pH}}_{\mathrm{DMO}}=\log \sum_{n=1}^{j} f_{j} \cdot 10^{\mathrm{pH}}$,

where $f_{j}$ is the fractional volume of the $j$ th compartment. Assuming a two-compartment model (i.e., FMLP-responding cells and nonresponders), the equation simplifies to:

$\overline{\mathrm{pH}}_{\mathrm{DMO}}=\log \left[f_{1} \cdot 10^{\mathrm{pH}}+f_{2} \cdot 10^{\mathrm{pHIP}}\right]$,

where the fractional volumes of the FMLP-responder and nonresponder subpopulations, $f_{1}$ and $f_{2}$, were taken as 0.6 and 0.4 , respectively; the $\mathrm{pH}_{\mathrm{i}}$ of the nonresponders was taken as the control or resting $\mathrm{pH}_{\mathrm{i}}$ in the absence of FMLP. In the figures and tables to follow, all reported $\mathrm{pH}_{\mathrm{i}}$ values obtained with FMLP have been corrected for the presence of subpopulations, by assuming $60 \%$ responding cells.

\section{Assay of superoxide radical generation}

Continuous assay technique. Superoxide generation was measured by the reduction of ferricytochrome $c$ as previously described (25). The production of $\mathrm{O}_{2}^{-}$was assayed continuously by means of a recorder attached to a spectrophotometer (model 250, Gilford Instrument Laboratories, Oberlin, $\mathrm{OH}$ ) in which the cuvette chamber was maintained at $37^{\circ} \mathrm{C}$ by means of circulating water. Experiments were performed in a total volume of $3.0 \mathrm{ml}$ containing $2 \times 10^{6}$ neutrophils and $25 \mu \mathrm{M}$ ferricytochrome $c$, to which $100 \mathrm{nM}$ FMLP was added as a concentrated stock solution.

Discontinuous assay technique. All experiments were performed in duplicate in a volume of $0.4 \mathrm{ml}$ in plastic tubes containing neutrophils (3-5 $\left.\times 10^{6} / \mathrm{ml}\right)$, ferricytochrome $c(75 \mu \mathrm{M})$, and FMLP at final concentrations of 4 or $100 \mathrm{nM}$. The tubes were placed at $37^{\circ} \mathrm{C}$ and periodically agitated. After $5 \mathrm{~min}$, the cells were pelleted by centrifugation at 8,000 $g$ for $30 \mathrm{~s}$ in a microcentrifuge. The supernatants were decanted and the amount of reduced cytochrome $c$ assayed as follows: $0.2 \mathrm{ml}$ of supernatant

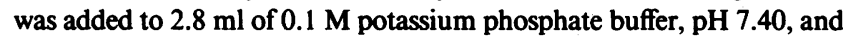
the absorbance spectrum was measured at $549 \mathrm{~nm}$ in a spectrophotometer (Gilford Instrument Laboratories). Utilizing potassium ferricyanide (Fisher Scientific Co.) and sodium dithionite (J. T. Baker Chemical Co., Phillipsburgh, NJ), the amount of reduced cytochrome $c$ and the total amount of cytochrome $c$ present were calculated using an extinction coefficient of $21.1 \mathrm{mM}^{-1} \mathrm{~cm}^{-1}$ at $550 \mathrm{~nm}$ (reduced-oxidized) (26). Appropriate control tubes demonstrated no spontaneous reduction of ferricytochrome $c$ by FMLP, amiloride, or any of the experimental media in the absence of neutrophils.

The addition of superoxide dismutase $(10 \mu \mathrm{g} / \mathrm{ml}$, Sigma Chemical Co.) to the complete reaction mixtures inhibited FMLP-induced cytochrome $c$ reduction by $>90 \%$, indicating that the reaction was specific for $\mathrm{O}_{2}^{-}$. Superoxide generation is expressed as nanomoles of cytochrome $c$ reduced per $10^{6}$ neutrophils. It should be mentioned that none of the experimental manipulations (i.e., conditions of varying $[\mathrm{Na}]_{0},[\mathrm{Na}]_{i}, \mathrm{pH}_{0}$, or $\mathrm{pH}_{\mathrm{i}}$ [see Results]) had any discernible effect on the time course of FMLP-stimulated $\mathrm{O}_{2}^{-}$generation which was complete by $5 \mathrm{~min}$ (see Fig. 1).

\section{Data analysis}

In several instances, the time course of $\mathrm{pH}_{\mathrm{i}}$ after exposure of cells to FMLP could be described by a single exponential equation of the form: $\mathrm{pH}_{t}=\mathrm{pH}_{\infty}-\left[\mathrm{pH}_{\infty}-\mathrm{pH}_{\text {initial }}\right] \exp (-k t)$

where $\mathrm{pH}_{\text {initial }}, \mathrm{pH}_{t}$, and $\mathrm{pH}_{\infty}$ are the $\mathrm{pH}_{\mathrm{i}}$ values at, respectively, zero time, time $t$, and after steady-state had been reached, and $k$ is the rate coefficient. Curves representing the equation were fitted to the various groups of data by the least-squares method. The initial rate of $\mathrm{pH}_{\mathrm{i}}$ change was derived from the expression $k\left[\mathrm{pH}_{\infty}-\mathrm{pH}_{\text {initial }}\right]$. In other cases, the $\mathrm{pH}_{\mathrm{i}}$ course was nearly linear over the period of study, and the slope of the linear regression represented the rate of $\mathrm{pH}_{\mathrm{i}}$ change.

In the statistical analyses, two-tailed comparisons were performed using multiple independent $t$ tests on difference scores (27).

\section{Results}

Effect of amiloride. Exposure of human neutrophils to an optimal dose of FMLP $(100 \mathrm{nM})$ led to the generation of $\mathrm{O}_{2}^{-}$as measured by the reduction of cytochrome $c$ (Fig. 1). Also shown is the time course of FMLP-induced $\mathrm{O}_{2}^{-}$production in the presence of $1 \mathrm{mM}$ amiloride, a drug which blocks $\mathrm{Na} / \mathrm{H}$ countertransport (17). In both cases, the release of $\mathrm{O}_{2}^{-}$was complete by $5 \mathrm{~min}$, i.e., the duration was unaffected by amiloride although the extent of release was reduced by about half. [It should be emphasized that none of the drugs or experimental conditions (see below) had any effect on the time course of FMLP-stimulated $\mathrm{O}_{2}^{-}$gen-

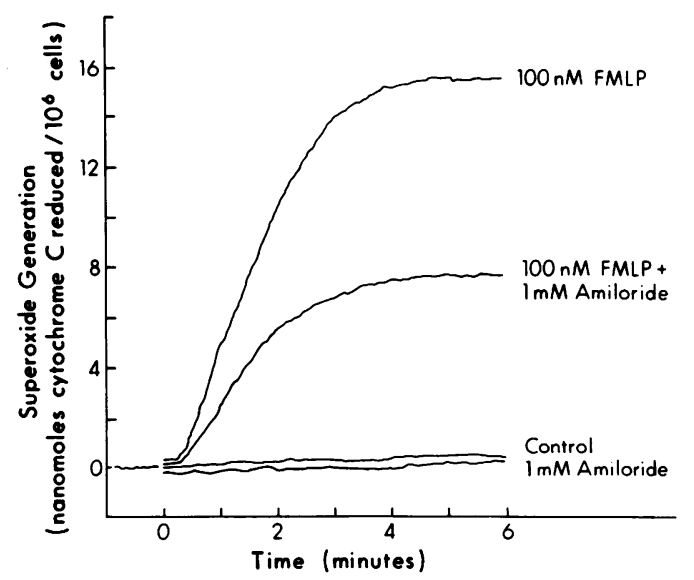

Figure 1. Time course of FMLP-induced $\mathrm{O}_{2}^{-}$generation. Neutrophils were suspended in standard medium $\left(140 \mathrm{mM} \mathrm{Na}, \mathrm{pH}_{0} 7.40\right)$ in the presence or absence of $1 \mathrm{mM}$ amiloride. At 0 time, FMLP was added to a final concentration of $100 \mathrm{nM}$. The generation of $\mathrm{O}_{2}^{-}$was measured by continuous assay using cytochrome $c$ (see Methods). The curves are tracings obtained with cells from a single donor. 
eration. Thus, the differences to be described reflect changes in the total amounts of $\mathrm{O}_{2}^{-}$release.]

The stimulation of respiratory burst activity was associated with an alkalinization of $\mathrm{pH}_{\mathrm{i}}$ from 7.22 to 7.80 (Fig. 2), which followed a time course similar, but not identical, to that of FMLP-induced $\mathrm{O}_{2}^{-}$release (Fig. 1). The rise in $\mathrm{pH}_{\mathrm{i}}$ is mediated by a chemotactic factor-activated exchange of external $\mathrm{Na}$ for internal $\mathrm{H}$. Fig. 2 also shows that $1 \mathrm{mM}$ amiloride reduced the initial rate of alkalinization elicited by FMLP from $0.288 \pm 0.036$ to $0.0061 \pm 0.0006 \mathrm{pH} / \mathrm{min}$, an inhibition of $98 \%$. However, at this concentration of amiloride, FMLP-stimulated $\mathrm{O}_{2}^{-}$production was only partially reduced, i.e., to a level $\sim 40 \%$ of the total in the absence of the drug (Fig. 1). From the data of Figs. 1 and 2 , it is immediately apparent that an alkalinization of $\mathrm{pH}_{\mathrm{i}}$ cannot be an absolute requirement for $\mathrm{O}_{2}^{-}$generation because a considerable amount of $\mathrm{O}_{2}^{-}$release was still observed in the presence of amiloride, which nearly abolished the $\mathrm{pH}_{\mathrm{i}}$ transient.

The dose dependencies of amiloride inhibition of the $\mathrm{pH}_{\mathrm{i}}$ and $\mathrm{O}_{2}^{-}$responses induced by $100 \mathrm{nM}$ FMLP are shown in Fig. 3. A Michaelis-Menten curve (apparent $K_{\mathrm{i}} 77.6 \pm 6.2 \mu \mathrm{M}$ ), fit to the $\mathrm{pH}_{\mathrm{i}}$ data by a nonlinear least-squares program, extrapolated to a point that could not be experimentally or statistically distinguished from 0 . This indicates that the $\mathrm{pH}_{\mathrm{i}}$ response was completely sensitive to amiloride. On the other hand, the $\mathrm{O}_{2}^{-}$ release data could be nicely fit by an empirical curve for which two components were assumed: $(a)$ an amiloride-sensitive fraction demonstrating Michaelis-Menten inhibition kinetics that was superimposed on $(b)$ an amiloride-insensitive background. Using a least-squares program, the data are evidently well fit by a curve composed of an amiloride-sensitive (apparent $K_{\mathrm{i}}$

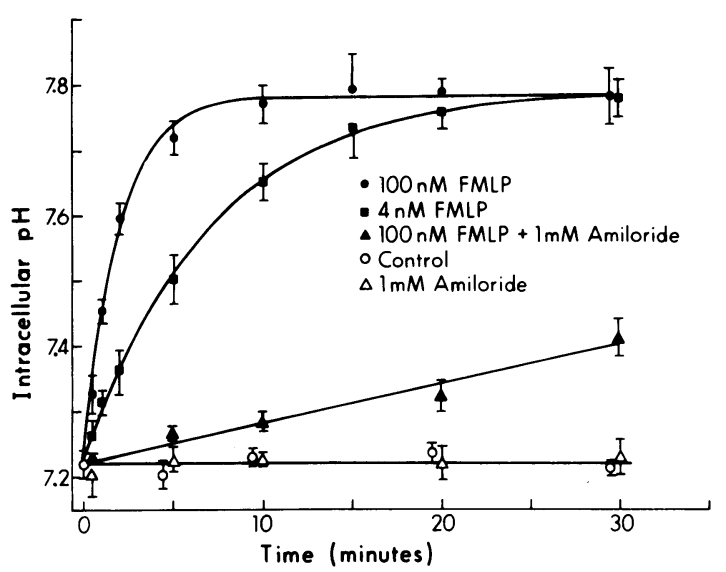

Figure 2. Time course of FMLP-induced $\mathrm{pH}_{\mathrm{i}}$ changes. Neutrophils were suspended in standard medium $\left(140 \mathrm{mM} \mathrm{Na}, \mathrm{pH}_{0} 7.40\right)$ in the presence $(\Delta, \Delta)$ or absence $(0, \bullet$ or $\square)$ of $1 \mathrm{mM}$ amiloride. At zero time, $4 \mathrm{nM}(\bullet)$ or $100 \mathrm{nM}$ FMLP $(\bullet, \Delta)$ was added. Controls, in the absence of FMLP, are also shown $(0, \Delta)$. At stated times, aliquots of the cell suspensions were taken for $\mathrm{pH}_{\mathrm{i}}$ measurements using $\left[{ }^{14} \mathrm{C}\right] \mathrm{DMO}$. The DMO-derived $\mathrm{pH}_{\mathrm{i}}$ values have been adjusted for the presence of neutrophil subpopulations, assuming 60\% FMLP-responding cells. Results represent the mean \pm standard error of the mean of three separate experiments, each performed in triplicate. For $4 \mathrm{nM}$ and $100 \mathrm{nM}$ FMLP, the curves are single exponential fits (Eq. 2) to the data. The initial rates were $0.0820 \pm 0.0124$ and $0.288 \pm 0.036 \mathrm{pH} /$ min, respectively; the final $\mathrm{pH}_{\mathrm{i}}$ values were $7.80 \pm 0.03$ and $7.79 \pm 0.02$, respectively. The $100 \mathrm{nM}$ FMLP plus $1 \mathrm{mM}$ amiloride data were fit to a straight line (slope $0.0061 \pm 0.0006 \mathrm{pH} / \mathrm{min}$ ). A horizontal line was drawn at 7.22, the average of the control and amiloride data points.

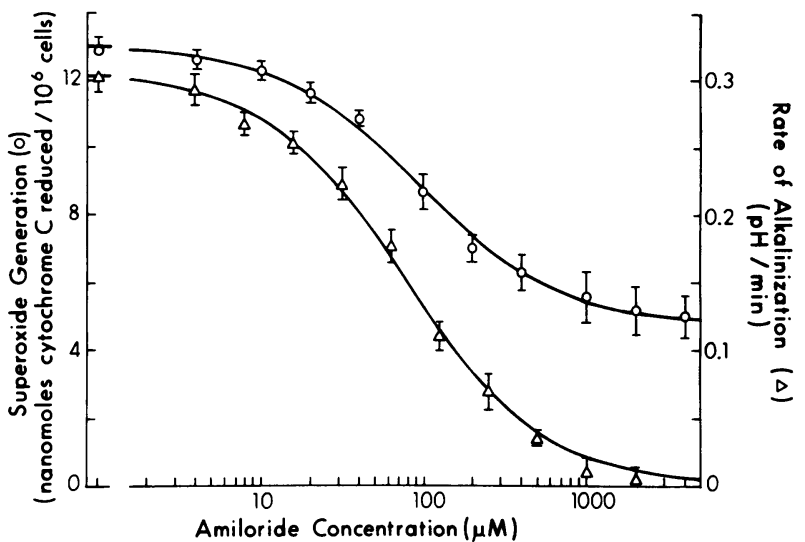

Figure 3. Effect of amiloride on FMLP-induced $\mathrm{pH}_{\mathrm{i}}$ and $\mathrm{O}_{2}^{-}$responses. All experiments were performed in standard medium $(140 \mathrm{mM} \mathrm{Na}$, $\mathrm{pH}_{0}$ 7.40). At zero time, $100 \mathrm{nM}$ FMLP was added to the neutrophil suspensions in the presence of varying concentrations of amiloride (0$4,000 \mu \mathrm{M})$. Intracellular $\mathrm{pH}$ data $(\Delta)$ : For each dose of amiloride, DMO-derived $\mathrm{pH}_{\mathrm{i}}$ was measured at two different time points $(0.5,1$, 2,5 , or $10 \mathrm{~min}$ as appropriate) during the course of the FMLP-stimulated alkalinization. The control (i.e., initial) $\mathrm{pH}_{\mathrm{i}}$ and the two measured $\mathrm{pH}_{\mathrm{i}}$ values were fitted to a single exponential equation (Eq. 2), from which the initial rate of $\mathrm{pH}_{\mathrm{i}}$ change was calculated. The data were adjusted for neutrophil subpopulations by assuming 60\% FMLPresponding cells. Results represent the mean \pm standard error of the mean of three separate experiments, each performed in triplicate. The data points, signifying the initial rates of FMLP-induced alkalinization, were fit by a least-squares program to a Michaelis-Menten inhibition equation which yielded an apparent $K_{\mathrm{i}}$ for amiloride of $77.6 \pm 6.2 \mu \mathrm{M}$. Superoxide radical generation (o): The amount of $\mathrm{O}_{2}^{-}$ release at 5 min was quantitated by cytochrome $c$ reduction using a discontinuous assay technique. Results represent the mean \pm standard error of the mean of three separate experiments, each performed in duplicate. The data were fit by a least-squares program which assumed two separate components: $(a)$ an amiloride-sensitive fraction, which demonstrated Michaelis-Menten inhibition (apparent $K_{\mathrm{i}}$ for amiloride $92.8 \pm 20.5 \mu \mathrm{M}$ and which accounted for $63.1 \pm 5.0 \%$ of the total), that was superimposed on $(b)$ an amiloride-resistant fraction (4.8 \pm 0.3 nmol cytochrome $c$ reduced $/ 10^{6}$ cells, which comprised $36.9 \pm 2.5 \%$ of the total).

$92.8 \pm 20.5 \mu \mathrm{M})$ fraction $(63.1 \pm 5.0 \%$ of total $)$ and an amilorideinsensitive fraction $(36.9 \pm 2.5 \%$ of total). It is of interest that, after taking this putative amiloride-resistant component of $\mathrm{O}_{2}^{-}$ generation into account, the apparent $K_{\mathrm{i}}$ 's for amiloride inhibition of the $\mathrm{pH}_{\mathrm{i}}$ response $(78 \mu \mathrm{M})$ and of the amiloride-sensitive component of $\mathrm{O}_{2}^{-}$production $(93 \mu \mathrm{M})$ were similar.

Effect of extracellular $\mathrm{Na}$. In order to test further whether $\mathrm{pH}_{\mathrm{i}}$ might at least partially regulate the $\mathrm{O}_{2}^{-}$response, a number of other modifications in the experimental design were employed. In this series of experiments, both the direction and degree of the $\mathrm{pH}_{\mathrm{i}}$ response induced by FMLP were varied by altering the $\mathrm{Na}$ gradient across the cell membrane, i.e., by changing the extracellular concentration of $\mathrm{Na}$. Fig. 4 shows the results of varying $[\mathrm{Na}]_{0}$ on FMLP-stimulated $\mathrm{pH}_{\mathrm{i}}$ and $\mathrm{O}_{2}^{-}$responses. For these studies, $[\mathrm{Na}]_{0}$ was varied from 140 to nominally $0 \mathrm{mM}$ by equimolar replacement with $N$-methyl-D-glucamine. As shown in

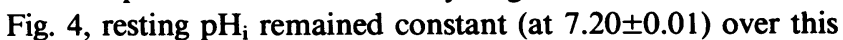
range of $[\mathrm{Na}]_{0}$. In contrast, the $\mathrm{pH}_{\mathrm{i}}$ (measured at $5 \mathrm{~min}$ ) in cells exposed to FMLP was strongly dependent on $[\mathrm{Na}]_{0}$. The $\mathrm{pH}_{\mathbf{i}}$ values in FMLP-responding cells rose as $[\mathrm{Na}]_{0}$ was increased 


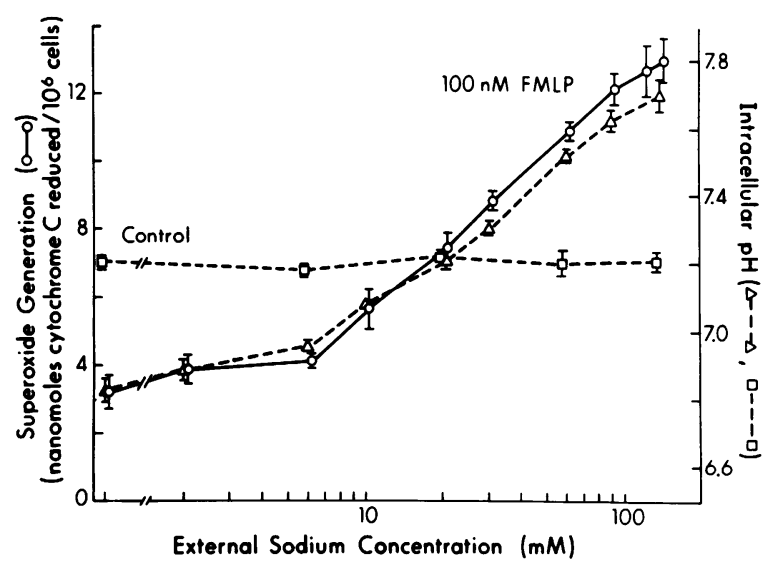

Figure 4. Effect of extracellular $\mathrm{Na}$ on FMLP-activated $\mathrm{pH}_{\mathrm{i}}$ and $\mathrm{O}_{2}^{-}$responses. Neutrophils were suspended at $\mathrm{pH}_{0} 7.40$ in media in which the concentration of external $\mathrm{Na}$ was varied between 0 and $140 \mathrm{mM}$ by equimolar replacement with $N$-methyl-D-glucamine. Experiments were performed in the presence $(0, \Delta)$ or absence $(\square)$ of $100 \mathrm{nM}$ FMLP. After 5 min of incubation, samples were taken for measurements of DMO-derived $\mathrm{pH}_{\mathrm{i}}(---)$ and $\mathrm{O}_{2}^{-}$generation (-). Control $\mathrm{O}_{2}^{-}$release under all conditions averaged $\leq 0.4 \mathrm{nmol}$ cytochrome $c$ reduced $/ 10^{6}$ cells (not shown). Results represent the mean \pm standard error of the mean of three $\left(\mathrm{pH}_{\mathrm{i}}\right)$ or four $\left(\mathrm{O}_{2}^{-}\right)$experiments.

between 0 and $140 \mathrm{mM}$. There was a crossover point (i.e., where FMLP caused no change in $\mathrm{pH}_{\mathrm{i}}$ ) at $[\mathrm{Na}]_{0} \sim 20 \mathrm{mM}$. This value corresponds to the point $\left([\mathrm{Na}]_{0}=19.5 \mathrm{mM}\right)$ at which $\mathrm{Na}$ and $\mathrm{H}$ are at chemical equilibrium across the membrane according to Eq. 1. It is of note that below [Na $]_{0} 20 \mathrm{mM}$, where the $\mathrm{Na}$ gradient is reversed (now outward and greater than the outwardly directed $\mathrm{H}$ gradient), the addition of FMLP leads to a relative acidification.

Fig. 4 also shows the amount of $\mathrm{O}_{2}^{-}$generated during a 5min exposure to FMLP under comparable conditions. The assays were terminated at $5 \mathrm{~min}$, by which time FMLP-induced $\mathrm{O}_{2}^{-}$ release under all conditions was complete. Although the production of $\mathrm{O}_{2}^{-}$elicited by FMLP was dependent on $[\mathrm{Na}]_{0}$, the relationship was not absolute in that appreciable (24-30\% of total) $\mathrm{O}_{2}^{-}$release occurred at very low $[\mathrm{Na}]_{0}(2 \mathrm{mM})$ or in the nominal absence of extracellular $\mathrm{Na}$. Chemical determinations of $\mathrm{Na}$ (by flame photometry) in the bathing medium indicated that the $\mathrm{Na}$ content did not exceed $0.5 \mathrm{mM}$ in nominally $\mathrm{Na}$ free medium. From the data, it is clear once again that an alkalinization of $\mathrm{pH}_{\mathrm{i}}$ cannot be an absolute requirement for $\mathrm{O}_{2}^{-}$ production because at an $[\mathrm{Na}]_{0}$ of $0-2 \mathrm{mM}$, where roughly $25 \%$ of total $\mathrm{O}_{2}^{-}$release occurs, the $\mathrm{pH}_{\mathrm{i}}$ of cells exposed to FMLP actually acidifies relative to control values.

Table I shows the relationship of $[\mathrm{Na}]_{0}$ to $\mathrm{O}_{2}^{-}$generation in cytochalasin B-treated cells. In the presence of $5 \mu \mathrm{g} / \mathrm{ml}$ cytochalasin $\mathrm{B}$, the amount of $\mathrm{O}_{2}^{-}$production induced by FMLP was constant and independent of external $\mathrm{Na}$. Thus, cytochalasin B apparently releases the system from its dependence on $[\mathrm{Na}]_{0}$. If the effect of [Na $]_{0}$, normally seen in the absence of cytochalasin B (Fig. 4), were related to $\mathrm{aH}_{\mathrm{i}}$ change, then one would predict that amiloride would have little or no effect on $\mathrm{O}_{2}^{-}$release by cytochalasin B-treated cells, an expectation verified by the data of Table I. However, amiloride ( $1 \mathrm{mM})$ did block the FMLPstimulated alkalinization in cytochalasin B-treated cells (data not shown: the $\mathrm{pH}_{\mathrm{i}}$ responses were indistinguishable in the absence or presence of cytochalasin $B$, where all of the cells respond
Table I. Lack of Effect of External Sodium on FMLP-induced $\mathrm{O}_{2}^{-}$Generation by Cytochalasin B-treated Cells

\begin{tabular}{cl}
\hline Conditions $\left(\left[\mathrm{Na}_{0}\right)\right.$ & FMLP-induced $\mathrm{O}_{2}^{-}$generation \\
\hline$m M$ & (nmol cytochrome c reduced $/ 10^{6}$ cells $)$ \\
0 & $24.7 \pm 3.6$ \\
1 & $22.3 \pm 2.3$ \\
5 & $23.8 \pm 3.1$ \\
10 & $22.5 \pm 1.4$ \\
30 & $21.8 \pm 3.1$ \\
60 & $24.8 \pm 1.8$ \\
90 & $22.5 \pm 2.9$ \\
140 & $23.8 \pm 2.9$ \\
$140+1 \mathrm{mM}$ amiloride & $24.2 \pm 3.4$ \\
\hline
\end{tabular}

Experiments were performed as in Fig. 4 except that neutrophils were pretreated with $5 \mu \mathrm{g} / \mathrm{ml}$ cytochalasin B for 5 min before the addition of $100 \mathrm{nM}$ FMLP. Results represent the mean \pm standard error of mean of three experiments.

to FMLP), similar to its efficacy in the absence of cytochalasin $\mathrm{B}$ (Figs. 2 and 3). In addition, the FMLP-activated $\mathrm{pH}_{\mathrm{i}}$ values as a function of $[\mathrm{Na}]_{0}$ were indistinguishable in normal (Fig. 4) vs. cytochalasin B-treated cells. At low external $\mathrm{Na}(\leq 2 \mathrm{mM})$, when $\mathrm{pH}_{\mathrm{i}}$ acidifies to $\sim 6.8$, cytochalasin B-treated neutrophils still produced normal quantities of $\mathrm{O}_{2}^{-}$(Table I) as compared with their counterparts in $140 \mathrm{mM} \mathrm{Na}$ medium where $\mathrm{pH}_{\mathrm{i}}$ alkalinized to $\sim 7.8$. This point further dramatizes the fact that $\mathrm{O}_{2}^{-}$production in the presence of cytochalasin $\mathrm{B}$ is independent of $\mathrm{pH}_{\mathrm{i}}$.

While clearly not an absolute requirement for $\mathrm{O}_{2}^{-}$release, the data thus far presented do not rule out a modulating or regulatory role for $\mathrm{pH}_{\mathrm{i}}$ on the $\mathrm{O}_{2}^{-}$response. Because optimal $\mathrm{O}_{2}^{-}$generation induced by FMLP is associated with an alkalinization of $\mathrm{pH}_{\mathrm{i}}$, a plausible hypothesis is that conditions which tend to increase $\mathrm{pH}_{\mathrm{i}}$ may facilitate $\mathrm{O}_{2}^{-}$production. The following series of experiments were undertaken to investigate this possibility.

Effect of extracellular $\mathrm{pH}$. The effect of altering extracellular $\mathrm{pH}\left(\mathrm{pH}_{0}\right)$ on the $\mathrm{pH}_{\mathrm{i}}$ and $\mathrm{O}_{2}^{-}$responses elicited by FMLP was tested. As shown in Fig. 5, varying $\mathrm{pH}_{0}$ from 5.9 to 8.0, while causing slight changes in the $\mathrm{pH}_{\mathrm{i}}$ of unstimulated cells, had a dramatic effect on the $\mathrm{pH}_{\mathrm{i}}$ of FMLP-activated cells. As previously reported (21), extracellular acidification or alkalinization resulted in small $\mathrm{pH}_{\mathrm{i}}$ changes in the same direction in resting cells. These $\mathrm{pH}_{\mathrm{i}}$ transients may reflect $\mathrm{H}$ or $\mathrm{OH}$ ion permeability. The $\mathrm{pH}_{\mathrm{i}}$ (measured at $5 \mathrm{~min}$ ) in FMLP-responders, however, was strongly dependent on $\mathrm{pH}_{0}$ (Fig. 5): raising $\mathrm{pH}_{0}$ from 5.9 to 8.0 increased the $\mathrm{pH}_{\mathrm{i}}$ of cells exposed to FMLP. There was a crossover point (i.e., where FMLP caused no $\mathrm{pH}_{\mathrm{i}}$ change) at $\mathrm{pH}_{0} \sim 6.5$, at which point $\mathrm{Na}$ and $\mathrm{H}$ are distributed in chemical equilibrium across the membrane.

The results of $\mathrm{O}_{2}^{-}$assays performed under similar conditions are also shown in Fig. 5. Relative to the amount of $\mathrm{O}_{2}^{-}$generated under normal conditions $\left(\mathrm{pH}_{0} 7.4\right)$, lowering $\mathrm{pH}_{0}$ towards 5.9 caused a reduction in the quantity of $\mathrm{O}_{2}^{-}$released during the 5min exposure to FMLP. In contrast, raising $\mathrm{pH}_{0}$ above 7.4 resulted in enhanced $\mathrm{O}_{2}^{-}$release. The quantities of $\mathrm{O}_{2}^{-}$produced at $\mathrm{pH}_{0} 7.7$ and $8.0(15.7 \pm 0.9$ and $16.5 \pm 0.6 \mathrm{nmol}$ cytochrome $c$ reduced $/ 10^{6}$ cells, respectively) were significantly greater $(P$ 


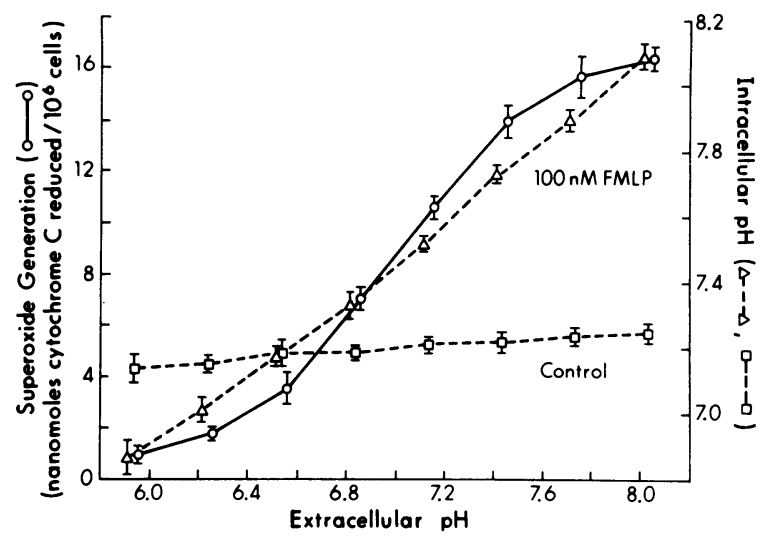

Figure 5. Effect of extracellular $\mathrm{pH}$ on FMLP-activated $\mathrm{pH}_{\mathrm{i}}$ and $\mathrm{O}_{2}^{-}$ responses. Neutrophils were suspended in $140 \mathrm{mM} \mathrm{Na}$ media of varying $\mathrm{pH}_{0}(5.9-8.0)$ in the presence $(0, \Delta)$ or absence $(\square)$ of $100 \mathrm{nM}$ FMLP. After 5 min of incubation, samples were taken for measurements of DMO-derived $\mathrm{pH}_{\mathrm{i}}(---)$ and $\mathrm{O}_{2}^{-}$generation (-). Control $\mathrm{O}_{2}^{-}$release under all conditions averaged $\leq 0.4 \mathrm{nmol}$ cytochrome $c$ reduced $/ 10^{6}$ cells (not shown). Results represent the mean \pm standard error of the mean of three $\left(\mathrm{pH}_{\mathrm{i}}\right)$ or four $\left(\mathrm{O}_{2}^{-}\right)$experiments.

$<0.05$ and $P<0.02$, respectively) than that at $\mathrm{pH}_{0} 7.4(14.0 \pm 0.7$ $\mathrm{nmol}$ reduced $/ 10^{6}$ cells). A comparison of the $\mathrm{pH}_{\mathrm{i}}$ and $\mathrm{O}_{2}^{-}$release data in the presence of FMLP indicates a positive correlation between the $\mathrm{pH}_{\mathrm{i}}$ value and the amount of $\mathrm{O}_{2}^{-}$release occurring in response to FMLP stimulation. In other experiments, $\mathrm{O}_{2}^{-}$was generated in a cell-free system by the reaction of photo-reduced riboflavin and oxygen according to the method of Winterbourn et al. (28). The amount of $\mathrm{O}_{2}^{-}$production detected by cytochrome $c$ was constant and independent of $\mathrm{pH}_{0}(5.9-8.0)$. These results suggest that the data of Fig. 5 were, in practice, little affected by any changes in the trapping efficiency of cytochrome $c$ over this $\mathrm{pH}$ range or by possible prolongation of the half-life of $\mathrm{O}_{2}^{-}$due to the presumed $\mathrm{pH}$-dependence of the dismutation reaction: $2 \mathrm{O}_{2}^{-}+2 \mathrm{H}^{+} \rightarrow \mathrm{H}_{2} \mathrm{O}_{2}+\mathrm{O}_{2}$.

It is important to bear in mind that our group has previously reported that the binding of tritiated-FMLP is not affected by the removal of extracellular $\mathrm{Na}$ and that binding appears to be independent of the nature of the monovalent cation in the bathing medium (6). Also, variations in $\mathrm{pH}_{0}$ over the range employed in this study (6-8) have only a modest effect on the binding of FMLP $(29,30)$. A slight reduction in binding has been reported as $\mathrm{pH}_{0}$ is raised from 7.4 to 8.0 , where the amount of $\mathrm{O}_{2}^{-}$generation is actually increasing (Fig. 5). Thus, the observed experimental results in Figs. 4 and 5 are unlikely to be due to variations in the binding of FMLP to its cell surface receptors.

Effect of intracellular $\mathrm{Na}$. Fig. 6 shows the results of experiments designed to test the effects of varying the initial internal $\mathrm{Na}$ concentration, $[\mathrm{Na}]_{i}$, on $\mathrm{pH}_{\mathrm{i}}$ values and $\mathrm{O}_{2}^{-}$generation after FMLP stimulation. For these studies, cells of different [Na]'s were prepared as follows: batches of Na-depleted cells $\left([\mathrm{Na}]_{i}\right.$ $\sim 2 \mathrm{mM}$ ) were prepared by incubation of cells $\left(1.5\right.$ hours, $\left.37^{\circ} \mathrm{C}\right)$ in Na-free medium, where $\mathrm{Na}$ was completely replaced by $\mathrm{N}$ methyl-D-glucamine (31). Batches of Na-loaded cells $\left([\mathrm{Na}]_{\mathrm{i}}\right.$ $\sim 50$ or $\sim 70 \mathrm{mM}$ ) were obtained by incubating cells for 1.5 or $3 \mathrm{~h}$, respectively, in ice-cold, $\mathrm{K}$-free saline as previously described (31). Normal Na cells $\left([\mathrm{Na}]_{i} \sim 30 \mathrm{mM}\right)$ were kept in standard ( $140 \mathrm{mM} \mathrm{Na}$ ) medium at $37^{\circ} \mathrm{C}$ throughout (31). After appropriate incubations, all cells were pelleted and resuspended in

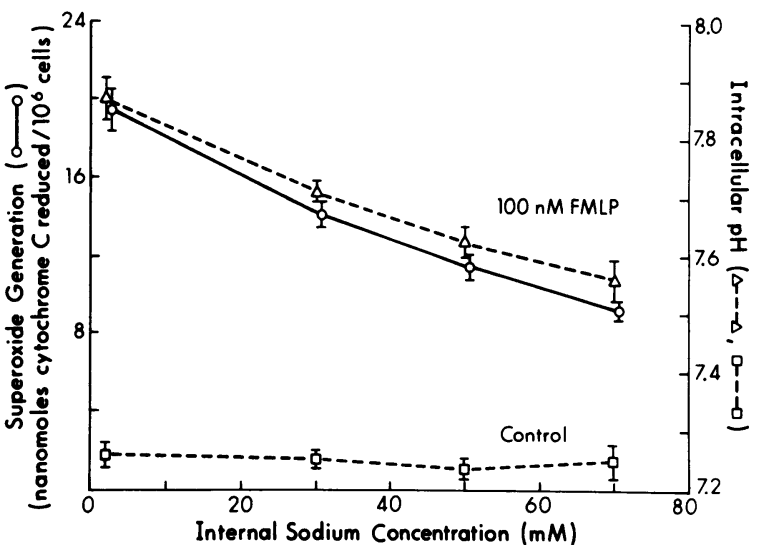

Figure 6. Effect of intracellular Na on FMLP-activated $\mathrm{pH}_{\mathrm{i}}$ and $\mathrm{O}_{2}^{-}$responses. Batches of neutrophils of varying internal $\mathrm{Na}$ concentrations were prepared as described in the text. As measured by flame photometry, the [Na $]_{i}$ 's of the different cell preparations were as follows: Nadepleted $(\leq 2 \mathrm{mM})$, normal $\mathrm{Na}(\sim 30 \mathrm{mM})$, and $\mathrm{Na}$-loaded $(\sim 50$ and $\sim 70 \mathrm{mM}$ ) (31). At 0 time, all cells were resuspended in standard medium $\left(140 \mathrm{mM} \mathrm{Na}, \mathrm{pH}_{0} 7.40\right)$ in the presence $(0, \Delta)$ or absence $(\square)$ of $100 \mathrm{nM}$ FMLP. After $5 \mathrm{~min}$ of incubation, samples were taken for measurements of DMO-derived $\mathrm{pH}_{\mathrm{i}}(---)$ and $\mathrm{O}_{2}^{-}$production (-). Control $\mathrm{O}_{2}^{-}$release under all conditions averaged $\leq 0.4 \mathrm{nmol}$ cytochrome $c$ reduced $/ 10^{6}$ cells (not shown). Results represent the mean \pm standard error of the mean of three $\left(\mathrm{pH}_{\mathrm{i}}\right)$ or six $\left(\mathrm{O}_{2}^{-}\right)$experiments.

$140 \mathrm{mM} \mathrm{Na}$ medium $\left(\mathrm{pH}_{0} 7.40\right)$ in the presence or absence of FMLP. Aliquots of the cell suspensions were then taken for $\mathrm{pH}_{\mathrm{i}}$ determinations and for measurements of $\mathrm{O}_{2}^{-}$release after $5 \mathrm{~min}$. Resting $\mathrm{pH}_{\mathrm{i}}$ was the same $(\sim 7.25)$ for all $[\mathrm{Na}]_{i}$ conditions. In each of the four sets, $\mathrm{pH}_{\mathrm{i}}$ (at $5 \mathrm{~min}$ ) rose after the addition of FMLP though the magnitudes of the $\mathrm{pH}_{\mathrm{i}}$ increments were dependent on the initial (i.e., resting) values of $[\mathrm{Na}]_{i}$. Relative to normal Na cells (initial $[\mathrm{Na}]_{\mathrm{i}} \sim 30 \mathrm{mM}$ ), the $\mathrm{pH}_{\mathrm{i}}$ of $\mathrm{Na}$-depleted cells (initial $[\mathrm{Na}]_{\mathrm{i}} \sim 2 \mathrm{mM}$ ) rose to a higher $\mathrm{pH}_{\mathrm{i}}$ value $(7.87 \pm 0.04$ vs. 7.71 \pm 0.02 ). By contrast, the $\mathrm{pH}_{\mathrm{i}}$ of FMLP-stimulated Naloaded cells (initial $[\mathrm{Na}]_{\mathrm{i}} \sim 70 \mathrm{mM}$ ) increased to only $7.56 \pm 0.05$. As also shown in Fig. 6, the $\mathrm{O}_{2}^{-}$generation responses (in nanomoles of cytochrome $c$ reduced $/ 10^{6}$ cells) to FMLP paralleled the $\mathrm{pH}_{\mathrm{i}}$ changes: relative to normal $\mathrm{Na}$ cells $(14.2 \pm 0.8)$, Nadepleted cells released more $(19.5 \pm 1.2, P$ vs. normal $\mathrm{Na}$ cells $<0.001)$, while Na-loaded cells released less $\mathrm{O}_{2}^{-}(9.3 \pm 0.6, P$ vs. normal Na cells $<0.002$ ).

Effect of intracellular $p H$. A series of experiments were performed to test the effects of variations in the initial $\mathrm{pH}_{\mathrm{i}}$ on FMLPstimulated $\mathrm{pH}_{\mathrm{i}}$ and $\mathrm{O}_{2}^{-}$production by $5 \mathrm{~min}$. For these studies, cells of more acidic $\mathrm{pH}_{\mathrm{i}}$ relative to normal $\left(\mathrm{pH}_{\mathrm{i}} \sim 7.25\right)$ were obtained by the undershoot of $\mathrm{pH}_{\mathrm{i}}$ after an $\mathrm{NH}_{4} \mathrm{Cl}$ prepulse and cells of more alkaline $\mathrm{pH}_{\mathrm{i}}$ were prepared by the overshoot of $\mathrm{pH}_{\mathrm{i}}$ after pretreatment of cells with $\mathrm{CO}_{2}$ (see Methods). For the experiments shown in Fig. 7, cells were preincubated with either $30 \mathrm{mM} \mathrm{NH}_{4} \mathrm{Cl}$, standard medium, $5 \% \mathrm{CO}_{2}$, or $18 \% \mathrm{CO}_{2}$, all at a constant $\mathrm{pH}_{0}$ of 7.40 . After $30 \mathrm{~min}$ at $37^{\circ} \mathrm{C}$, the cells were spun down and resuspended in $140 \mathrm{mM} \mathrm{Na}$ medium, $\mathrm{pH}_{0} 7.40$, in the presence or absence of FMLP. Samples were then taken for $\mathrm{pH}_{\mathrm{i}}$ measurements at $5 \mathrm{~min}$.

In the absence of FMLP, the $\mathrm{pH}_{\mathrm{i}}$ of control cells after the $\mathrm{NH}_{4} \mathrm{Cl}$ undershoot and $\mathrm{CO}_{2}$ overshoot was rapidly recovering (i.e., returning to near normal values by $15 \mathrm{~min}$ [21]). For clarity, 


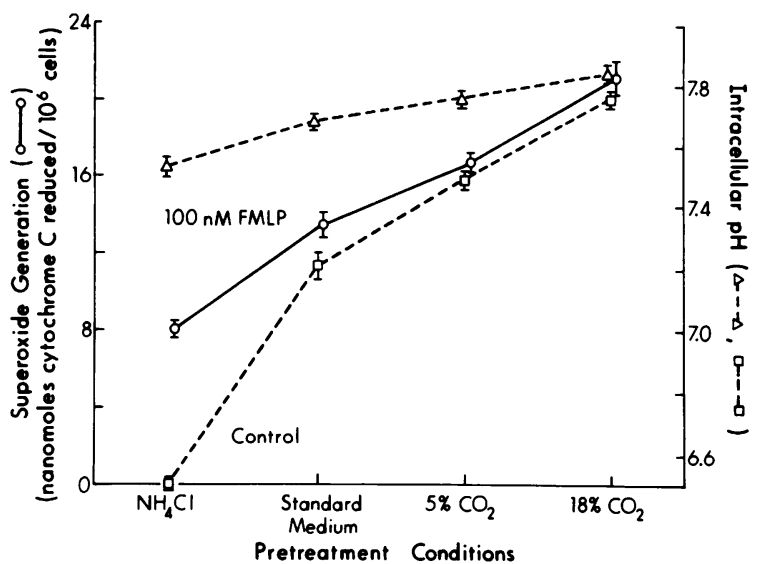

Figure 7. Effect of intracellular $\mathrm{pH}$ on FMLP-activated $\mathrm{pH}_{\mathrm{i}}$ and $\mathrm{O}_{2}^{-}$responses. Batches of neutrophils of different $\mathrm{pH}_{\mathrm{i}}$ were prepared by pretreating cells with either $30 \mathrm{mM} \mathrm{NH}_{4} \mathrm{Cl}, 5 \% \mathrm{CO}_{2}, 18 \% \mathrm{CO}_{2}$, or standard medium, each at $\mathrm{pH}_{0} 7.40$ (see Methods). At zero time, all cells were resuspended in standard medium $\left(140 \mathrm{mM} \mathrm{Na}, \mathrm{pH}_{0} 7.40\right)$ in the presence $(0, \Delta)$ or absence $(\square)$ of $100 \mathrm{nM}$ FMLP. After 5 min of incubation, samples were taken for measurements of DMO-derived $\mathrm{pH}_{\mathrm{i}}$ $(---)$ and $\mathrm{O}_{2}^{-}$production (-). In the absence of FMLP, the $\mathrm{pH}_{\mathrm{i}}$ of control cells previously exposed to $30 \mathrm{mM} \mathrm{NH}_{4} \mathrm{Cl}, 5 \% \mathrm{CO}_{2}$, or $18 \%$ $\mathrm{CO}_{2}$ was rapidly recovering (i.e., returning towards the normal resting $\mathrm{pH}_{\mathrm{i}}$ of $\sim 7.2$ ). For clarity, only the initial $\mathrm{pH}_{\mathrm{i}}$ values (ם) of control cells are shown for comparison. Control $\mathrm{O}_{2}^{-}$release under all conditions averaged $\leq 0.4 \mathrm{nmol}$ cytochrome $c$ reduced $/ 10^{6}$ cells (not shown). Results represent the mean \pm standard error of the mean of three $\left(\mathrm{pH}_{\mathrm{i}}\right)$ or four $\left(\mathrm{O}_{2}^{-}\right)$experiments.

only the initial $\mathrm{pH}_{\mathrm{i}}$ values are shown (Fig. 7). In each of the four batches of cells, the addition of FMLP led to an alkalinization of $\mathrm{pH}_{\mathrm{i}}$ though both the relative $\mathrm{pH}_{\mathrm{i}}$ increments $\left(\Delta \mathrm{pH}_{\mathrm{i}} \mathrm{s}\right)$ as well as the absolute $\mathrm{pH}_{\mathrm{i}}$ values induced by FMLP differed among the cell preparations and were related to the initial $\mathrm{pH}_{\mathrm{i}}$ 's. The $\Delta \mathrm{pH}_{\mathrm{i}}$ was least in cells preincubated with $18 \% \mathrm{CO}_{2}$, where initial $\mathrm{pH}_{\mathrm{i}}$ was highest (7.76 \pm 0.03 ), though $\mathrm{pH}_{\mathrm{i}}$ in response to FMLP alkalinized to the highest level (7.84 \pm 0.04$)$. By comparison, $\Delta \mathrm{pH}_{\mathrm{i}}$ was greatest in cells preincubated with $30 \mathrm{mM} \mathrm{NH}_{4} \mathrm{Cl}$, where initial $\mathrm{pH}_{\mathrm{i}}$ was lowest $(6.50 \pm 0.02)$, but $\mathrm{pH}_{\mathrm{i}}$ in response to FMLP rose to only $7.53 \pm 0.04$.

For convenience, the $\mathrm{O}_{2}^{-}$responses of separate aliquots of these cells are also shown in Fig. 7. There was a good correlation between the $\mathrm{pH}_{\mathrm{i}}$ induced by FMLP at $5 \mathrm{~min}$ and the quantity of $\mathrm{O}_{2}^{-}$produced. Cells pretreated with $18 \% \mathrm{CO}_{2}$, where $\mathrm{pH}_{\mathrm{i}}$ rose to the highest value (7.84) generated the most $\mathrm{O}_{2}^{-}(21.3 \pm 1.0$ nmol cytochrome $c$ reduced $/ 10^{6}$ cells), while cells pretreated with $30 \mathrm{mM} \mathrm{NH}_{4} \mathrm{Cl}$, where $\mathrm{pH}_{\mathrm{i}}$ alkalinized to only 7.53 , generated the least $\mathrm{O}_{2}^{-}\left(8.1 \pm 0.5 \mathrm{nmol}\right.$ reduced $/ 10^{6}$ cells). In both instances, the amounts of $\mathrm{O}_{2}^{-}$released were significantly different $(P$ $<0.01$ ) from that produced by cells kept in standard medium $\left(13.5 \pm 0.8 \mathrm{nmol}\right.$ reduced $/ 10^{6}$ cells) where $\mathrm{pH}_{\mathrm{i}}$ rose to an intermediate value of $7.68 \pm 0.03$ after the addition of FMLP. Thus, it appears that the critical effect in regulating the $\mathrm{O}_{2}^{-}$response relates to the absolute level to which $\mathrm{pH}_{\mathrm{i}}$ rises rather than to the relative increment in $\mathrm{pH}_{\mathrm{i}}$ induced by FMLP.

The preceding sections all provide evidence in support of the argument that an alkalinization of $\mathrm{pH}_{\mathrm{i}}$ facilitates $\mathrm{O}_{2}^{-}$generation in the presence of FMLP. However, this relationship does not appear to hold true in the absence of FMLP. For cells pretreated with $18 \% \mathrm{CO}_{2}, \mathrm{pH}_{\mathrm{i}}$ rose initially to $\sim 7.75(21)$, a value similar to that achieved by normal $\mathrm{Na}$ cells exposed to $100 \mathrm{nM}$ FMLP in $140 \mathrm{mM} \mathrm{Na}(19)$, yet no $\mathrm{O}_{2}^{-}$release could be detected during a 30-min assay. A further dissociation between an alkalinization of $\mathrm{pH}_{\mathrm{i}}$ and function in the absence of FMLP could be achieved by other means: namely, exposure of cells to $\mathrm{NH}_{4} \mathrm{Cl}$ or to monensin, an ionophore that promotes the exchange of alkali metal cations, especially $\mathrm{Na}$, for $\mathrm{H}$ (32). When cells are exposed to $30 \mathrm{mM} \mathrm{NH}_{4} \mathrm{Cl}$ at $\mathrm{pH}_{0} 7.40, \mathrm{pH}_{\mathrm{i}}$ rises dramatically to $\sim 7.65$ and then gradually recovers to near control levels (7.25) within $30 \mathrm{~min}(21)$. The $\mathrm{pH}_{\mathrm{i}}$ of cells exposed to $10 \mu \mathrm{M}$ monensin in $140 \mathrm{mM} \mathrm{Na}$ medium at $\mathrm{pH} 7.40$ undergoes an alkalinization whose time course and final extent $(\sim 7.80)$ are indistinguishable from that obtained with $100 \mathrm{nM}$ FMLP (19). However, no $\mathrm{O}_{2}^{-}$ production could be detected during $30 \mathrm{~min}$ of incubation in either instance, i.e., with $\mathrm{NH}_{4} \mathrm{Cl}$ or monensin, even though the alkalinization in the latter case is sustained. These results indicate that an alkalinization of $\mathrm{pH}_{\mathrm{i}}$, per se, is not a sufficient trigger for $\mathrm{O}_{2}^{-}$production. Thus, FMLP must be generating some additional excitatory signal that is critical to the $\mathrm{O}_{2}^{-}$response.

Subthreshold FMLP concentrations. In a previous publication (6), our group reported that the dose-response range for stimulation of ${ }^{22} \mathrm{Na}$ fluxes by FMLP extended over 2.5-3 logs, from $\sim 0.1 \mathrm{nM}$ to a maximum at $\sim 100 \mathrm{nM}$. In contrast, the dose-response range for the induction of $\mathrm{O}_{2}^{-}$release by FMLP is narrow, comprising only $1 \mathrm{log}$, from 10 to $100 \mathrm{nM}$. We have been unable to show a statistically significant or reproducible increase in $\mathrm{O}_{2}^{-}$production above control values in the presence of $4 \mathrm{nM}$ FMLP. This is true even though ${ }^{22} \mathrm{Na}$ uptake into cells exposed to $4 \mathrm{nM}$ FMLP for $5 \mathrm{~min}$ is roughly half the amount achieved in response to $100 \mathrm{nM}$ FMLP, an optimal dose (6). In that $\mathrm{Na}$ influx via $\mathrm{Na} / \mathrm{H}$ exchange occurs by a $1: 1$ countertransport of $\mathrm{Na}$ for $\mathrm{H}(18,19)$, the uptake of ${ }^{22} \mathrm{Na}$ should mirror the $\mathrm{pH}_{\mathrm{i}}$ change. Therefore, one would predict that in cells exposed to $4 \mathrm{nM} \mathrm{FMLP}, \mathrm{pH}_{\mathrm{i}}$ would rise at a slower rate than in cells treated with $100 \mathrm{nM}$ FMLP, that the degree of alkalinization at $5 \mathrm{~min}$ in the former case should be about one-half of the latter, but that steady-state $\mathrm{pH}_{\mathrm{i}}$ would be the same in the two instances (i.e., chemical equilibrium distribution for $\mathrm{Na}$ and $\mathrm{H}$ as dictated by Eq. 1). These predictions are verified by the data of Fig. 2 . As can be seen, the $\mathrm{pH}_{\mathrm{i}}$ of cells exposed to $4 \mathrm{nM}$ FMLP approached $\sim 7.80$ by $\sim 30 \mathrm{~min}$, the same value reached at $\sim 10$ min in cells exposed to $100 \mathrm{nM}$ FMLP. However, with $4 \mathrm{nM}$ FMLP, no $\mathrm{O}_{2}^{-}$release above control could be detected during a 30-min incubation (data not shown).

These data imply that even an alkalinization of this magnitude (of $\sim 0.6$ to $\mathrm{pH}_{\mathrm{i}} \sim 7.80$ ) induced by FMLP is not a sufficient trigger if the $\mathrm{pH}_{\mathrm{i}}$ rise is sufficiently slow or delayed. Apparently, if the induced $\mathrm{pH}_{\mathrm{i}}$ change is to modulate the functional activity of these cells, it must do so early, presumably within the first few seconds when the critical triggering signal is generated by FMLP. Whatever the exact nature of this event, we hypothesized that it might be potentiated by a rise in $\mathrm{pH}_{\mathrm{i}}$. We predicted, therefore, that if the rate and/or amplitude of the alkalinization could be increased by modifying the experimental conditions, then $\mathrm{O}_{2}^{-}$release in response to $4 \mathrm{nM}$ FMLP might become measurable in that some threshold effect would then be exceeded. To test this hypothesis, we used $\mathrm{Na}$-depleted cells and cells pretreated with $18 \% \mathrm{CO}_{2}$, two maneuvers associated with enhanced $\mathrm{O}_{2}^{-}$release in cells stimulated by $100 \mathrm{nM}$ FMLP (Figs. 6 and 7). The results of these experiments are shown in Table II. In the case of initially Na-depleted cells and for cells after a $\mathrm{CO}_{2}$ prepulse, $\mathrm{pH}_{\mathrm{i}}$ in response to $4 \mathrm{nM}$ FMLP was higher than 
Table II. Potentiation of a Subthreshold FMLP Dose by Intracellular Alkalinization

\begin{tabular}{|c|c|c|c|c|}
\hline \multirow[b]{2}{*}{ Cells* } & \multicolumn{2}{|l|}{$\mathrm{pH}_{\mathrm{i}} \ddagger$} & \multicolumn{2}{|c|}{$\mathrm{O}_{2}^{-}$generationf } \\
\hline & Control & $\begin{array}{l}4 \mathrm{nM} \\
\text { FMLP }\end{array}$ & Control & $\begin{array}{l}4 \mathrm{nM} \\
\text { FMLP }\end{array}$ \\
\hline Normal Na & $7.28 \pm 0.01$ & $7.51 \pm 0.03$ & $0.4 \pm 0.2$ & $0.4 \pm 0.1$ \\
\hline Na-depleted & $7.27 \pm 0.03$ & $7.61 \pm 0.03$ & $0.3 \pm 0.1$ & $3.2 \pm 0.3^{\prime \prime}$ \\
\hline $18 \% \mathrm{CO}_{2}$-pretreated & $7.46 \pm 0.02 \S$ & $7.63 \pm 0.02$ & $0.4 \pm 0.1$ & $5.2 \pm 0.5^{\prime \prime}$ \\
\hline
\end{tabular}

* Batches of normal $\mathrm{Na}\left([\mathrm{Na}]_{\mathrm{i}} \sim 30 \mathrm{mM}\right)$ and $\mathrm{Na}$-depleted $\left([\mathrm{Na}]_{\mathrm{i}} \sim 2 \mathrm{mM}\right)$ cells were prepared by preincubating neutrophils in standard medium (140 mM $\mathrm{Na}, \mathrm{pH}_{0} 7.40$ ) or in $\mathrm{Na}$-free medium ( $\mathrm{N}$-methyl-D-glucamine replacement), respectively, for $1.5 \mathrm{~h}$ at $37^{\circ} \mathrm{C}$ (see text). Another aliquot of the cell suspension was exposed to $18 \% \mathrm{CO}_{2}\left(\mathrm{pH}_{0} 7.40\right)$ for $30 \mathrm{~min}$. At zero time, all cells were resuspended in standard medium ( $\left.140 \mathrm{mM} \mathrm{Na}, \mathrm{pH}_{0} 7.40\right)$ in the presence or absence of $4 \mathrm{nM}$ FMLP.

¥ At 5 min, DMO-derived $\mathrm{pH}_{\mathrm{i}}$ and $\mathrm{O}_{2}^{-}$release (from cytochrome $c$ reduction) were measured. The amount of $\mathrm{O}_{2}^{-}$generation is expressed as nanomoles of cytochrome $c$ reduced per $10^{6}$ neutrophils. The results are the mean \pm standard error of the mean of three separate experiments.

$\S$ The initial $\mathrm{pH}_{\mathrm{i}}$ value was $7.79 \pm 0.03$.

" $P$ vs. control $<0.005$.

for normal $\mathrm{Na}$ cells at $2 \mathrm{~min}$ (not shown) and at $5 \mathrm{~min}$. In both instances, significant amounts of $\mathrm{O}_{2}^{-}$release were now observed ( $P$ vs. control $<0.005$ ). Under these conditions, there were no differences in either the amounts or kinetics of specific $\left[{ }^{3} \mathrm{H}\right]$ FMLP binding to the neutrophils. Thus, the finding of increased $\mathrm{O}_{2}^{-}$ generation by $\mathrm{Na}$-depleted cells and by those pretreated with $18 \% \mathrm{CO}_{2}$ are unlikely to be due to altered receptor-ligand interactions.

\section{Discussion}

The regulation of $\mathrm{pH}_{\mathrm{i}}$ is currently receiving considerable attention as the importance of $\mathrm{pH}_{\mathrm{i}}$ to a number of cell functions becomes increasingly apparent. For example, $\mathrm{pH}_{\mathrm{i}}$ has been shown to play a role in egg fertilization, mechanical properties of muscle, cell growth and division, and epithelial transport and secretion (for reviews, see References 22 and 33). Recently, proposals have been set forth that several functions of neutrophils may be regulated by their $\mathrm{pH}_{\mathrm{i}}(16,34)$. The present study was undertaken to define the potential role of chemotactic factor-induced $\mathrm{pH}_{\mathrm{i}}$ transients in human neutrophils on a specific functional response: that of $\mathrm{O}_{2}^{-}$production. The results demonstrate a direct relationship between an intracellular alkalinization and the amount of $\mathrm{O}_{2}^{-}$generated by FMLP-activated cells. In an analogous way, a correlation between an alkalinization and the functional responses of other stimulated cells has been reported in rat splenic lymphocytes (35) and in hamster pulmonary fibroblasts (36), where the proliferative responses to mitogens or growth factors, as well as the $\mathrm{pH}_{\mathrm{i}}$ changes, are inhibited by amiloride. Comparable results are also seen for serotonin secretion by thrombinstimulated human platelets (37), for insulin release by rat and mouse pancreatic islet cells (38), and for the early developmental behavior following sea urchin egg fertilization (39). All of these observations strongly implicate $\mathrm{pH}_{\mathrm{i}}$ as an important element in stimulus-response coupling.

Our group (19) and others (14) have previously reported that exposure of human or rabbit neutrophils to FMLP leads to an alkalinization of $\mathrm{pH}_{\mathrm{i}}$. In contrast to the single phase of alkalinization in FMLP-activated human neutrophils noted in the present study, Molski et al. (14) observed a biphasic $\mathrm{pH}_{\mathrm{i}}$ response in rabbit neutrophils: a small $(\sim 0.05 \mathrm{U})$ acidification within the first minute followed by a sustained alkalinization of $\sim 0.2 \mathrm{U}$. These magnitudes are understandably smaller than those reported in this paper which were corrected for the presence of the $60 \%$ FMLP-responding subpopulation. However, the reason for the disparity in the data regarding the initial relative acidification is not at all apparent. The nature of these $\mathrm{pH}_{\mathrm{i}}$ transients has been examined in some detail. The alkalinization results from activation of an amiloride-sensitive $\mathrm{Na} / \mathrm{H}$ countertransport mechanism that, under normally prevailing conditions, mediates a 1:1 exchange of external $\mathrm{Na}$ for internal $\mathrm{H}$ leading to a rise in $\mathrm{pH}_{\mathrm{i}}$ from $\sim 7.25$ to $\sim 7.80$ (19). Several lines of evidence indicate that this alkalinization cannot be an obligatory requirement or sine qua non for $\mathrm{O}_{2}^{-}$generation. First, roughly $40 \%$ of $\mathrm{O}_{2}^{-}$release induced by $100 \mathrm{nM}$ FMLP occurs in the presence of $1 \mathrm{mM}$ amiloride (Figs. 1 and 3), conditions under which the alkalinization is almost completely abolished (Figs. 2 and 3). Second, compared to the response at $[\mathrm{Na}]_{0} 140 \mathrm{mM}, \sim 25 \%$ of maximal $\mathrm{O}_{2}^{-}$production occurs in the nominal absence of extracellular $\mathrm{Na}$, where, because the $\mathrm{Na}$ gradient has been reversed, $\mathrm{pH}_{\mathrm{i}}$ actually acidifies after FMLP stimulation (Fig. 4). Third, exposure of cells to $4 \mathrm{nM}$ FMLP leads to an alkalinization of the same degree (to $~ 7.8$ ) at $30 \mathrm{~min}$ as that observed with $100 \mathrm{nM}$ FMLP at 10 min (Fig. 2), yet causes no $\mathrm{O}_{2}^{-}$release. Fourth, in the absence of FMLP, raising $\mathrm{pH}_{\mathrm{i}}$ to 7.7-7.8 by means of $\mathrm{NH}_{4} \mathrm{Cl}$, monensin, or after a $\mathrm{CO}_{2}$ prepulse resulted in no demonstrable $\mathrm{O}_{2}^{-}$generation above control. The foregoing arguments leave little doubt that some other, as yet, unidentified early excitatory signal induced by FMLP is critical to activation of the enzyme system responsible for the generation of $\mathrm{O}_{2}^{-}$.

Nonetheless, it appears that the $\mathrm{pH}_{\mathrm{i}}$ level seems to play a modulating or regulatory role at one or more steps in the pathway leading to $\mathrm{O}_{2}^{-}$release. For instance, when either $[\mathrm{Na}]_{0},[\mathrm{Na}]_{i}$, $\mathrm{pH}_{0}$, or $\mathrm{pH}_{\mathrm{i}}$ was varied independently, there was a direct, positive correlation between the $\mathrm{pH}_{\mathrm{i}}$ value in FMLP-stimulated cells and the amount of $\mathrm{O}_{2}^{-}$released by $5 \mathrm{~min}$. It is important to remember that the 5-min $\mathrm{pH}_{\mathrm{i}}$ value cannot, in and of itself, be the direct modulating factor in that $\mathrm{O}_{2}^{-}$production is complete by 4-5 min. Rather, the relationship of $\mathrm{pH}_{\mathrm{i}}$ to this functional response may best be viewed in terms of this $\mathrm{pH}_{\mathrm{i}}$ 's reflecting the $\mathrm{pH}_{\mathrm{i}}$ level prevailing at some critical juncture in time. Presumably, this period occurs early in the time course of events, possibly within the first few seconds after ligand-receptor interaction.

During the respiratory burst, there is a net generation of protons which can be detected as an acidification of the bathing medium $(40,41)$. At first sight, it might indeed seem that the associated $\mathrm{pH}_{\mathrm{i}}$ changes observed here are a direct result of the proton efflux and that an intracellular alkalinization is not unexpected. Actually, there is no theoretical reason to suppose that an acid efflux must be coupled to or be mirrored by an intracellular alkalinization. In fact, no a priori conclusion can be drawn about either the magnitude or direction of $\mathrm{pH}_{\mathrm{i}}$ from the quantity of $\mathrm{H}^{+}$equivalents entering the bathing medium. (a) Cytosolic $\mathrm{pH}_{\mathrm{i}}$ may remain unaffected if the $\mathrm{H}^{+}$equivalents are generated at the membrane surface, a distinct possibility in this case considering the plasma membrane localization of the $\mathrm{O}_{2}^{-}$-forming NADPH oxidase. (b) Cytosolic $\mathrm{pH}_{\mathrm{i}}$ may actually fall as $\mathrm{H}^{+}$equivalents are generated inside, some of them diffusing into the external medium. (c) Cytosolic $\mathrm{pH}_{\mathbf{i}}$ may rise because of a separate mechanism such as an exchange of internal $\mathrm{H}$ for external $\mathrm{Na}$. 
It is important to emphasize that FMLP-activated $\mathrm{Na} / \mathrm{H}$ exchange is a distinct, independent phenomenon, divorced from the release of protons associated with the formation of $\mathrm{O}_{2}^{-}$or its reaction products. This point is graphically demonstrated by the data of Fig. 2 wherein the final $\mathrm{pH}_{\mathrm{i}}$ in stimulated cells is the same ( 7.80) after exposure to either 4 or $100 \mathrm{nM}$ FMLP even though no $\mathrm{O}_{2}^{-}$generation can be detected at the lower stimulus concentration, whereas the latter elicits a lot.

The mechanism by which $\mathrm{pH}_{\mathrm{i}}$ exerts its regulatory role is unclear at present. In other cells, where this question has been addressed, numerous metabolic events have been shown to be $\mathrm{pH}$-sensitive. These include intracellular calcium and cyclic nucleotide levels, protein and DNA synthesis, energy metabolism, contractile apparatus, and membrane permeability to ions (for review, see Reference 33). It is tempting to speculate that the potentiation of $\mathrm{O}_{2}^{-}$production seen at relatively alkaline $\mathrm{pH}_{\mathrm{i}}$ values represents the titration of a critical functional group(s) on a protein(s) in the pathway leading to $\mathrm{O}_{2}^{-}$generation. From the data presented, this protein might be expected to display a $\mathrm{pH}$ optimum in the region of 8.0. A number of investigators working with cell-free preparations derived from zymosan- or phorbol myristate acetate-stimulated neutrophils have all reported a pH optimum for the $\mathrm{O}_{2}^{-}$-forming activity (NADPH oxidoreductase) in the range of 7.0-7.5 (42-44). A slight decrease in activity is generally seen as $\mathrm{pH}$ is raised to 8.0. Thus, it appears unlikely that the observed enhancement of $\mathrm{O}_{2}^{-}$-generating capacity at alkaline $\mathrm{pH}_{\mathrm{i}}$ can be attributed to a direct effect on this enzyme. However, it should be remembered that the properties of any integral membrane protein may be different in intact cells as compared to those in partially purified subcellular preparations. It seems then that the mechanistic explanation underlying the effect of $\mathrm{pH}_{\mathrm{i}}$ on $\mathrm{O}_{2}^{-}$generation awaits further identification of the $\mathrm{pH}$ dependencies of the reaction sequence leading to the production of $\mathrm{O}_{2}^{-}$.

In this context, it is intriguing that Bormann et al. (45) have recently reported activation by FMLP of a phospholipase activity in rabbit neutrophil membranes. The optimal $\mathrm{pH}$ was 8.0-8.5 with activity rapidly decreasing at $\mathrm{pH}$ values below 7.0 . It is tempting to speculate that $\mathrm{pH}_{\mathrm{i}}$ might be acting through this route. This is especially appealing because changes in the turnover of phospholipids, in particular the release and subsequent metabolism of arachidonic acid to prostaglandins, leukotrienes, and other mediators, are thought to be important biochemical events in chemotactic factor-induced activation of neutrophils.

In this study, relatively high (i.e., millimolar) concentrations of amiloride were required to block FMLP-stimulated $\mathrm{Na} / \mathrm{H}$ exchange and $\mathrm{O}_{2}^{-}$generation. In other cell types, these concentrations have also been shown to inhibit $\mathrm{Na}$ conductive pathways (46), $\mathrm{Na} / \mathrm{Ca}$ exchange (47), $\mathrm{Na} / \mathrm{K}$ ATPase activity (48), and bicarbonate transport (49), and to penetrate the cell interior to affect protein synthesis (17). Thus, a question arises as to the specificity of amiloride for the $\mathrm{Na} / \mathrm{H}$ exchanger of human neutrophils: whether the effect of amiloride on $\mathrm{O}_{2}^{-}$production is related solely to abrogation of $\mathrm{Na} / \mathrm{H}$ exchange rather than to some other property. It is unlikely that the drug's suppression of $\mathrm{O}_{2}^{-}$release is related to inhibition of $\mathrm{Na}$ channels in that we have found that amiloride is without effect on passive, electrodiffusive $\mathrm{Na}$ fluxes in human neutrophils (18). In addition, an effect on $\mathrm{Na} / \mathrm{Ca}$ exchange is unlikely since amiloride does not inhibit ${ }^{45} \mathrm{Ca}$ fluxes (15) and since benzyl-amiloride, which blocks $\mathrm{Na} / \mathrm{Ca}$ exchange in neutrophils by $\sim 75 \%$ (unpublished observations), does not alter FMLP-induced $\mathrm{O}_{2}^{-}$generation. Finally, an effect on the $\mathrm{Na} / \mathrm{K}$ pump can be ruled out because ouabain has no effect on $\mathrm{O}_{2}^{-}$release (7) and because amiloride does not inhibit the active pump-mediated efflux of ${ }^{22} \mathrm{Na}$ from neutrophils (unpublished observations).

In contrast to the observation of a reduction in the amount of $\mathrm{O}_{2}^{-}$release with decreasing $[\mathrm{Na}]_{0}$, Della Bianca and co-workers (50) reported enhancement of $\mathrm{O}_{2}^{-}$generation at low [Na] (equivalent replacement by $\mathrm{K}$ ). The authors noted that the increase in functional responsiveness correlated with an increase in the affinity and number of FMLP receptors (51). The explanation for the difference between this and the present study is not immediately apparent. However, it should be pointed out that the studies of Rossi and colleagues were conducted in Cafree media containing $1 \mathrm{mM} \mathrm{KCN}, 17 \mathrm{mM}$ phosphate, and 5 $\mu \mathrm{g} / \mathrm{ml}$ cytochalasin B, conditions very different from those reported here. Moreover, altered receptor function caused by the different experimental media cannot explain our results because a 1.5-h preincubation in Na-free medium (to cause internal $\mathrm{Na}$ depletion) or a 30 -min pretreatment with $18 \% \mathrm{CO}_{2}$, two maneuvers associated with higher FMLP-induced $\mathrm{pH}_{\mathrm{i}}$ and $\mathrm{O}_{2}^{-}$generation, had no effect on either the time course or extent of $\left[{ }^{3} \mathrm{H}\right]$ FMLP binding at $4 \mathrm{nM}$ FMLP.

Pfefferkorn (52) has presented evidence that several functional responses of human monocytes, including $\mathrm{O}_{2}^{-}$generation, occur independently of external $\mathrm{Na}$, but that a dependence on $[\mathrm{Na}]_{0}$ could be induced by pretreating cells with isotonic $\mathrm{NH}_{4} \mathrm{Cl}$. The author implied that the $[\mathrm{Na}]_{0}$ dependence of a variety of neutrophil functions might be an artifact resulting from the use of $\mathrm{NH}_{4} \mathrm{Cl}$ to lyse contaminating erythrocytes during the purification procedure. Although this observation could be invoked to explain our original data on $\mathrm{O}_{2}^{-}$production (6), it cannot explain the present results because the neutrophils were rid of erythrocytes by hypotonic lysis. In addition, it should be noted that other investigators, who did not use the $\mathrm{NH}_{4} \mathrm{Cl}$ lysis technique, have also observed a number of different neutrophil responses, such as $\mathrm{O}_{2}^{-}$generation (7), chemotaxis (4), and degranulation $(7,53)$, to be dependent on external $\mathrm{Na}$.

In summary, the data presented in this study indicate a modulating effect of intracellular $\mathrm{pH}$ on $\mathrm{O}_{2}^{-}$generation by FMLP-activated human neutrophils. These results suggest that other functional responses of these cells may be regulated by their $\mathrm{pH}_{\mathrm{i}}$.

\section{Acknowledgments}

We acknowledge the expert technical assistance of William $\mathrm{H}$. Miller and Arabella R. Kizzart and the secretarial skills of Karen Zimmerman. We are especially grateful to Dr. Paul De Weer for supplying the leastsquares programs and to Mr. Ronald Ratzlaff for his diligent efforts in connection with the computer files and graphic displays. We also wish to thank Dr. Edward J. Cragoe, Jr. of Merck, Sharp \& Dohme for his gift of amiloride.

This study was supported by the Veterans Administration and an Arthritis Foundation Clinical Research Center grant.

\section{References}

1. Henson, P. M., M. H. Ginsberg, and D. C. Morrison. 1978. Mechanisms of mediator release by inflammatory cells. In Membrane Fusion. G. Poste and G. L. Nicholson, editors. Elsevier/North-Holland, Amsterdam. 407-508.

2. Weissmann, G., H. M. Korchak, H. D. Perez, J. E. Smolen, I. M. Goldstein, and S. T. Hoffstein. 1979. Leukocytes as secretory organs of inflammation. Adv. Inflammation Res. 1:95-112. 
3. Sha'afi, R. I., and P. H. Naccache. 1981. Ionic events in neutrophil chemotaxis and secretion. Adv. Inflammation Res. 2:115-148.

4. Showell, H. J., and E. L. Becker. 1976. The effects of external $\mathrm{K}^{+}$ and $\mathrm{Na}^{+}$on the chemotaxis of rabbit peritoneal neutrophils. J. Immunol. 116:99-105.

5. Seligmann, B., E. Gallin, G. Martin, W. Shain, and J. I. Gallin. 1980. Interaction of chemotactic factors with human polymorphonuclear leukocytes: Studies using a membrane potential-sensitive dye. J. Membr. Biol. 52:257-272.

6. Simchowitz, L., and I. Spilberg. 1979. Chemotactic-factor-induced generation of superoxide radicals by human neutrophils. Evidence for the role of sodium. J. Immunol. 123:2428-2435.

7. Korchak, H. M., and G. Weissmann. 1980. Stimulus-response coupling in the human neutrophil. Transmembrane potential and the role of extracellular $\mathrm{Na}^{+}$. Biochim. Biophys. Acta. 601:180-194.

8. Korchak, H. M., and G. Weissmann. 1978. Changes in membrane potential of human granulocytes antecede the metabolic responses to surface stimulation. Proc. Natl. Acad. Sci. USA. 75:3818-3822.

9. Simchowitz, L., J. P. Atkinson, and I. Spilberg. 1980. Stimulusspecific deactivation of chemotactic factor-induced cyclic AMP response and superoxide generation by human neutrophils. J. Clin. Invest. 66: 736-747.

10. Sklar, L. A., A. J. Jesaitis, R. G. Painter, and C. G. Cochrane. 1981. The kinetics of neutrophil activation. The response to chemotactic peptides depends upon whether ligand-receptor interaction is rate-limiting. J. Biol. Chem. 256:9909-9914.

11. Naccache, P. H., H. J. Showell, E. L. Becker, and R. I. Sha'afi. 1977. Changes in ionic movements across rabbit polymorphonuclear leukocyte membranes during lysosomal enzyme release. Possible ionic basis for lysosomal enzyme release. J. Cell Biol. 75:635-649.

12. Junge, D. 1981. Nerve and Muscle Excitation, 2nd edition. Sinauer Associates, Sunderland.

13. Naccache, P. H., H. J. Showell, E. L. Becker, and R. I. Sha'afi. 1977. Transport of sodium, potassium, and calcium across rabbit polymorphonuclear leukocyte membranes. Effect of chemotactic factor. $J$. Cell Biol. 73:428-444.

14. Molski, T. F. P., P. H. Naccache, M. Volpi, L. M. Wolpert, and R. I. Sha'afi. 1980. Specific modulation of the intracellular $\mathrm{pH}$ of rabbit neutrophils by chemotactic factors. Biochem. Biophys. Res. Commun. 94:508-514.

15. Sha'afi, R. I., T. F. P. Molski, and P. Naccache. 1981. Chemotactic factors activate differentiable permeation pathways for sodium and calcium in rabbit neutrophils. Biochem. Biophys. Res. Commun. 99:12711276.

16. Sha'afi, R. I., P. H. Naccache, T. F. P. Molski, and M. Volpi. 1982. Chemotactic stimuli-induced changes in the $\mathrm{pH}_{\mathrm{i}}$ of rabbit neutrophils. In Intracellular pH: Its Measurement, Regulation and Utilization in Cellular Functions. Nuccitelli, R., and D. W. Deamer, editors. Alan R. Liss, Inc., New York. 513-525.

17. Benos, D. J. 1982. Amiloride: a molecular probe of sodium transport in tissues and cells. Am. J. Physiol. 242:C131-C145.

18. Simchowitz, L. 1985. Chemotactic factor-induced activation of $\mathrm{Na}^{+} / \mathrm{H}^{+}$exchange in human neutrophils. I. Sodium fluxes. J. Biol. Chem. In press.

19. Simchowitz, L. 1985. Chemotactic factor-induced activation of $\mathrm{Na}^{+} / \mathrm{H}^{+}$exchange in human neutrophils. II. Intracellular $\mathrm{pH}$ changes. J. Biol. Chem. In press.

20. Boyüm, A. 1968. Isolation of mononuclear cells and granulocytes from human blood. Scand. J. Clin. Lab. Invest. 21(Suppl. 97):77-89.

21. Simchowitz, L., and A. Roos. 1985. Regulation of intracellular pH in human neutrophils. J. Gen. Physiol. 85:443-470.

22. Roos, A., and W. F. Boron. 1981. Intracellular pH. Physiol. Rev. 61:296-433.

23. Boron, W. F., and A. Roos. 1976. Comparison of microelectrode, DMO, and methylamine methods for measuring intracellular pH. Am. J. Physiol. 231:799-809.
24. Seligmann, B., T. M. Chused, and J. I. Gallin. 1981. Human neutrophil heterogeneity identified using flow microfluorometry to monitor membrane potential. J. Clin. Invest. 68:1125-1131.

25. Simchowitz, L., L. C. Fischbein, I. Spilberg, and J. P. Atkinson. 1980. Induction of a transient elevation in intracellular levels of adenosine-3',5'-cyclic monophosphate by chemotactic factors: an early event in human neutrophil activation. J. Immunol. 124:1482-1491.

26. Van Gelder, B. F., and E. C. Slater. 1962. The extinction coefficient of cytochrome C. Biochim. Biophys. Acta. 58:593-595.

27. Edwards, A. L. 1967. The $t$ test for means. In Statistical Methods. Holt, Rinehart, and Winston, New York. 2nd edition. 200-225.

28. Winterbourn, C. C., R. E. Hawkins, M. Brian, and R. W. Carrell. 1975. The estimation of red cell superoxide dismutase activity. J. Lab. Clin. Med. 85:337-341.

29. Schiffman, E., S. Aswanikumar, K. Venkatasubramanian, B. A. Corcoran, C. B. Pert, J. Brown, E. Gross, A. R. Day, D. J. Freer, A. H. Showell, and E. L. Becker. 1980. Some characteristics of the neutrophil receptor for chemotactic peptides. FEBS (Fed. Eur. Biochem. Soc. Lett. 117:1-7.

30. Mehta, J., and I. Spilberg. 1983. Heterologous receptor population for a chemotactic factor f-met-leu-phe on the human neutrophil. Effect of $\mathrm{pH}$ and temperature. Inflammation. 7:301-309.

31. Simchowitz, L., I. Spilberg, and P. De Weer. 1982. Sodium and potassium fluxes and membrane potential of human neutrophils. Evidence for an electrogenic sodium pump. J. Gen. Physiol. 79:453-479.

32. Pressman, B. C. 1969. Mechanism of action of transport-mediating antibiotics. Ann. N.Y. Acad. Sci. 147:829-841.

33. Busa, W. B. and R. Nuccitelli. 1984. Metabolic regulation via intracellular pH. Am. J. Physiol. 246:R409-438.

34. Segal, A. W., M. Geisow, R. Garcia, A. Harper, and R. Miller. 1981. The respiratory burst of phagocytic cells is associated with a rise in vacuolar pH. Nature (Lond.). 290:406-409.

35. Gerson, D. F., H. Kiefer, and W. Eufe. 1982. Intracellular pH of mitogen-stimulated lymphocytes. Science (Wash. DC). 216:1009-1010.

36. L'Allemain, G., S. Paris, and J. Pouyssegur. 1984. Growth factor action and intracellular $\mathrm{pH}$ regulation in fibroblasts. Evidence for a major role of the $\mathrm{Na}^{+} / \mathrm{H}^{+}$antiport. J. Biol. Chem. 259:5809-5815.

37. Simons, E. R., D. B. Schwartz, and N. E. Norman. 1982. Stimulus response coupling in human platelets: thrombin-induced changes in $\mathbf{p H}_{\mathrm{i}}$. In Intracellular pH: Its Measurement, Regulation, and Utilization in Cellular Functions. Nuccitelli, R., and D. W. Deamer, editors. Alan R. Liss, Inc., New York. 463-482.

38. Pace, C. S., J. T. Tarvin, and J. S. Smith. 1983. Stimulus-secretion coupling in $\beta$-cells: modulation by pH. Am. J. Physiol. 244:E3-E18.

39. Johnson, J. J., D. Epel, and M. Paul. 1976. Intracellular pH and activation of sea urchin eggs after fertilization. Nature (Lond.). 262:661664.

40. van Zwieten, R., R. Wever, M. N. Hamers, R. S. Weening, and D. Roos. 1981. Extracellular proton release by stimulated neutrophils. J. Clin. Invest. 68:310-313.

41. Borregaard, N., J. H. Schwartz, and A. I. Tauber. 1984. Proton secretion by stimulated neutrophils. Significance of hexose monophosphate shunt activity as source of electrons and protons for the respiratory burst. J. Clin. Invest. 74:455-459.

42. Babior, B. M., J. T. Curnutte, and B. J. McMurrich. 1976. The particulate superoxide-forming system from human neutrophils. Properties of the system and further evidence supporting its participation in the respiratory burst. J. Clin. Invest. 58:989-996.

43. Tauber, A. I. and E. J. Goetzl. 1979. Structural and catalytic properties of the solubilized superoxide-generating activity of human polymorphonuclear leukocytes. Solubilization, stabilization in solution, and partial characterization. Biochemistry. 18:5576-5583.

44. Green, T., D. E. Wu, and M. K. Wirtz. 1983. The $\mathrm{O}_{2}^{-}$generating oxidoreductase of human neutrophils: evidence of an obligatory requirement for calcium and magnesium for expression of catalytic activity. Biochem. Biophys. Res. Commun. 110:973-978. 
45. Bormann, B. J., C. K. Huang, W. M. Mackin, and E. L. Becker. 1984. Receptor-mediated activation of a phospholipase $A_{2}$ in rabbit neutrophil plasma membrane. Proc. Natl. Acad. Sci. USA. 81:767-770.

46. Cuthbert, A. W., and W. K. Shun. 1974. Binding of amiloride to sodium channels in frog skin. Mol. Pharmacol. 10:880-891.

47. Kaczorowski, G. J., F. Bavros, J. K. Dethmers, M. J. Trumble, and E. J. Cragoe, Jr. 1985. Inhibition of $\mathrm{Na}^{+} / \mathrm{Ca}^{2+}$ exchange in pituitary plasma membrane vesicles by analogues of amiloride. Biochemistry. 24: 1394-1403.

48. Soltoff, S. P., and L. J. Mandel. 1983. Amiloride directly inhibits the $\left(\mathrm{Na}^{+}, \mathrm{K}^{+}\right)$ATPase activity of rabbit kidney proximal tubules. Science (Wash. DC). 220:957-959.

49. McKinney, T. D., and M. B. Burg. 1978. Bicarbonate absorption by rabbit cortical collecting tubules in vitro. Am. J. Physiol. 234:F141F145.

50. Della Bianca, V., P. Bellavite, P. De Togni., R. Fumarulo, and F. Rossi. 1983. Studies on stimulus-response coupling in human neu- trophils. I. Role of monovalent cations in the respiratory and secretory response to $\mathrm{N}$-formylmethionylleucylphenylalanine. Biochim. Biophys. Acta. 755:497-505.

51. De Togni, P., V. Della Bianca, P. Bellavite, M. Grzeskowiak, and F. Rossi. 1983. Studies on stimulus-response coupling in human neutrophils. II. Relationships between the effects of changes of external ionic composition on the properties of $\mathrm{N}$-formylmethionylleucylphenylalanine receptors and on the respiratory and secretory responses. Biochim. Biophys. Acta. 755:506-513.

52. Pfefferkorn, L. C. 1984. Transmembrane signaling: an ion-fluxindependent model for signal transduction by complexed $\mathrm{F}_{\mathrm{c}}$ receptors. J. Cell Biol. 99:2231-2240.

53. Showell, H. J., P. H. Naccache, R. I. Sha'afi, and E. L. Becker. 1977. The effects of extracellular $\mathrm{K}^{+}, \mathrm{Na}^{+}$and $\mathrm{Ca}^{++}$on lysosomal enzyme secretion from polymorphonuclear leukocytes. J. Immunol. 119:804811. 